\title{
A I Idade do Ferro na Alcáçova de Santarém (Portugal): OS RESUlTADOS DA CAMPANHA DE $2001^{*}$
}

\author{
ELISA DE SOUSA \\ Ana Margarida Arruda \\ UNIARQ (Centro de Arqueologia da Universidade de Lisboa)
}

Recibido: 04/09/2017

Revisado: 10/04/2018
Aceptado: $31 / 05 / 2018$

Publicado: 29/06/2018

\section{RESUMO}

As escavações realizadas, em 2001, na Alcáçova de Santarém (Portugal) permitiram identificar uma extensa diacronia de ocupação que se iniciou durante os momentos finais da Idade do Bronze e que se prolongou até à actualidade. Neste trabalho, pretende-se apresentar os dados relativos ao período sidérico que, de acordo com os materiais recuperados (ânforas, cerâmica de engobe vermelho, cinzenta, pintada, comum e manual), se terá iniciado em torno a finais do século VIII / inícios do século VII a.n.e., estendendo-se até momentos avançados do século VI a.n.e. A evolução da cultura material recolhida durante esta intervenção permitiu avaliar, sequencialmente, o impacto da chegada dos primeiros agentes fenício-ocidentais no quadro das tradições autóctones da comunidade que habitou a Alcáçova de Santarém durante a $1^{\underline{a}}$ metade do $1^{0}$ milénio a.n.e.
ABSTRACT

Excavations carried out in 2001, in Alcáçova of Santarem (Portugal) have identified an extensive diachronic occupation that began during the Late Bronze Age and lasted until nowadays. In this work, we intend to present the data concerning the Iron Age occupation that, according to the associated materials (amphorae, red slipware, gray ware, painted ware, common ware and handmade productions), started during the late $8^{\text {th }} /$ early 7 th century BCE. and lasted until the late 6th century BCE. The evolution of material culture, collected during this intervention, allow to evaluate, sequentially, the impact of the arrival of the first Western Phoenicians in the context of the indigenous traditions of the community that inhabited Alcáçova de Santarém during the 1st half of the 1st millennium BCE.

\section{KEY WORDS}

Tagus estuary; Iron Age; Material culture; Phoenician; Native communities.
Estuário do Tejo; Idade do Ferro; Cultura material; Fenícios; Comunidades indígenas.

* Trabalho realizado no quadro do Projecto "Fenícios no Estuário do Tejo" PTDC/EPH-ARQ/4901/2012.

e.sousa@campus.ul.pt a.m.arruda@letras.ulisboa.pt 


\section{INTRODUÇÃo}

A Alcáçova de Santarém constitui um dos sítios arqueológicos mais emblemáticos da fachada ocidental atlântica do território português. Localizada na margem direita do rio Tejo, ocupa um planalto elevado, com $106 \mathrm{~m}$ de altitude e uma extensão de cerca de 4,5 ha, que lhe confere uma posição estratégica quer em termos de defensabilidade, quer no âmbito de um extenso controlo visual sobre o território envolvente (Arruda 1999-2000: 137-138) (Fig. 1).

Os múltiplos, extensos e prolongados trabalhos de campo efectuados no local (Fig. 2), dirigidos por uma das signatárias (A.M.A.), permitiram reconhecer e valorizar o importante património arqueológico do local, que se perpetua desde os momentos finais da Idade do Bronze até à actualidade, sem que se verifiquem significativas descontinuidades no quadro da ocupação humana (Arruda 19992000: 138-139). Esta mesma intensidade ocupacional implicou, naturalmente, constantes remo- delações construtivas que afectaram, de forma por vezes desigual, as estratigrafias mais antigas da Alcáçova, dificultando, em algumas ocasiões, a leitura diacrónica dos diferentes momentos cronológicos, ainda que tal não tenha impedido a sua interpretação (Arruda 1993, 1999-2000; 2005a; 2005b).

O trabalho que aqui apresentamos ganha uma particular importância por ter decorrido numa área consideravelmente extensa, com cerca de $43^{\mathrm{m} 2}$ (Sector 2), na qual foi possível escavar em profundidade, tendo-se atingido o substrato geológico (Fig. 3). Os diversos níveis de ocupação associáveis à Idade do Ferro foram agrupados, de acordo com as suas relações estratigráficas, em seis fases distintas que não têm, por vezes, uma diferenciação clara em termos cronológicos. Com efeito, alguns destes momentos terão sido formados em períodos possivelmente curtos, não sendo possível observar distinções acentuadas nos respectivos horizontes artefactuais. Em outros casos, porém, surgem alterações no quadro da cultura material que refletem, de forma mais clara,

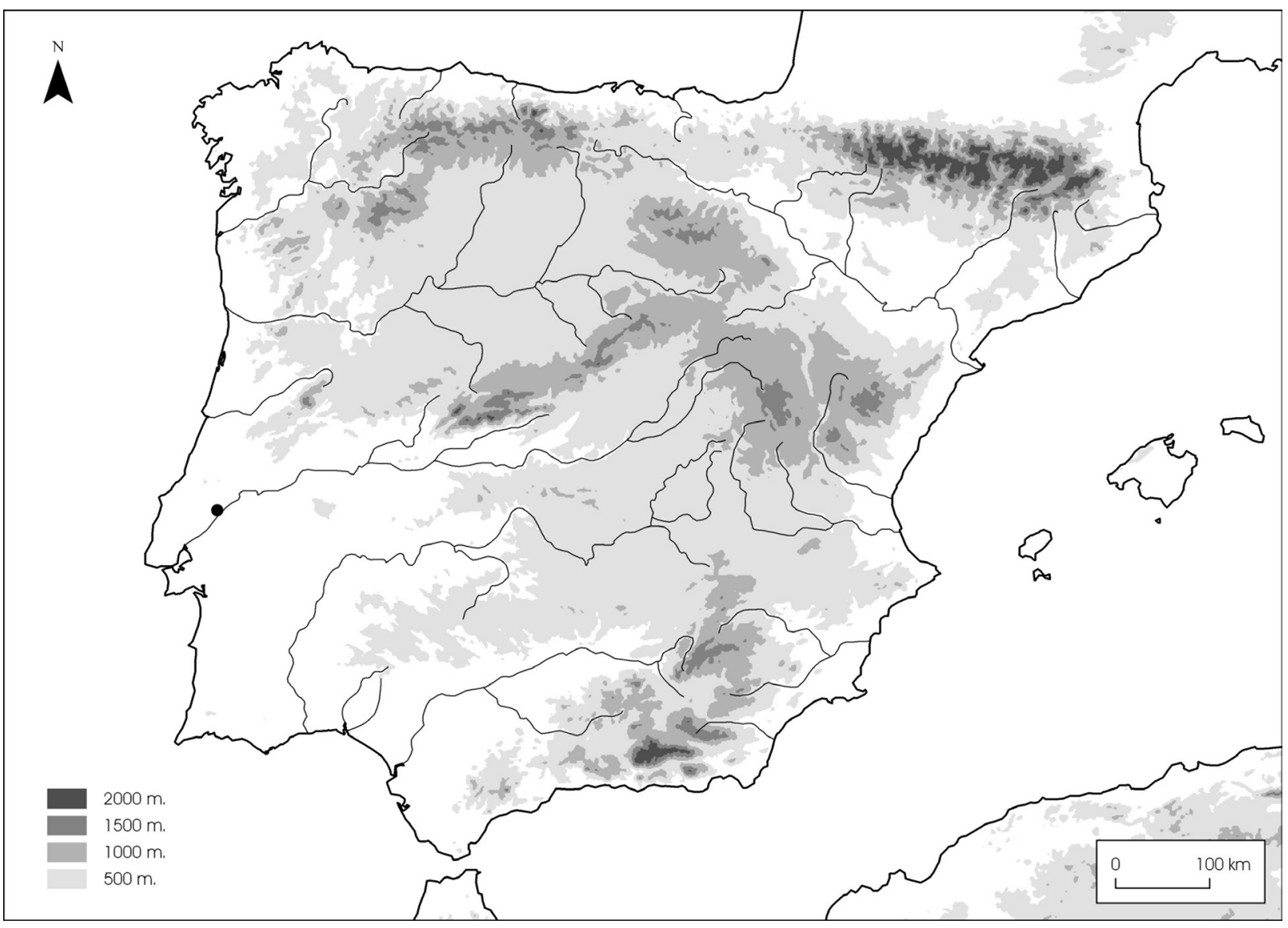

Fig. 1 - Localização de Santarém na Península Ibérica. 


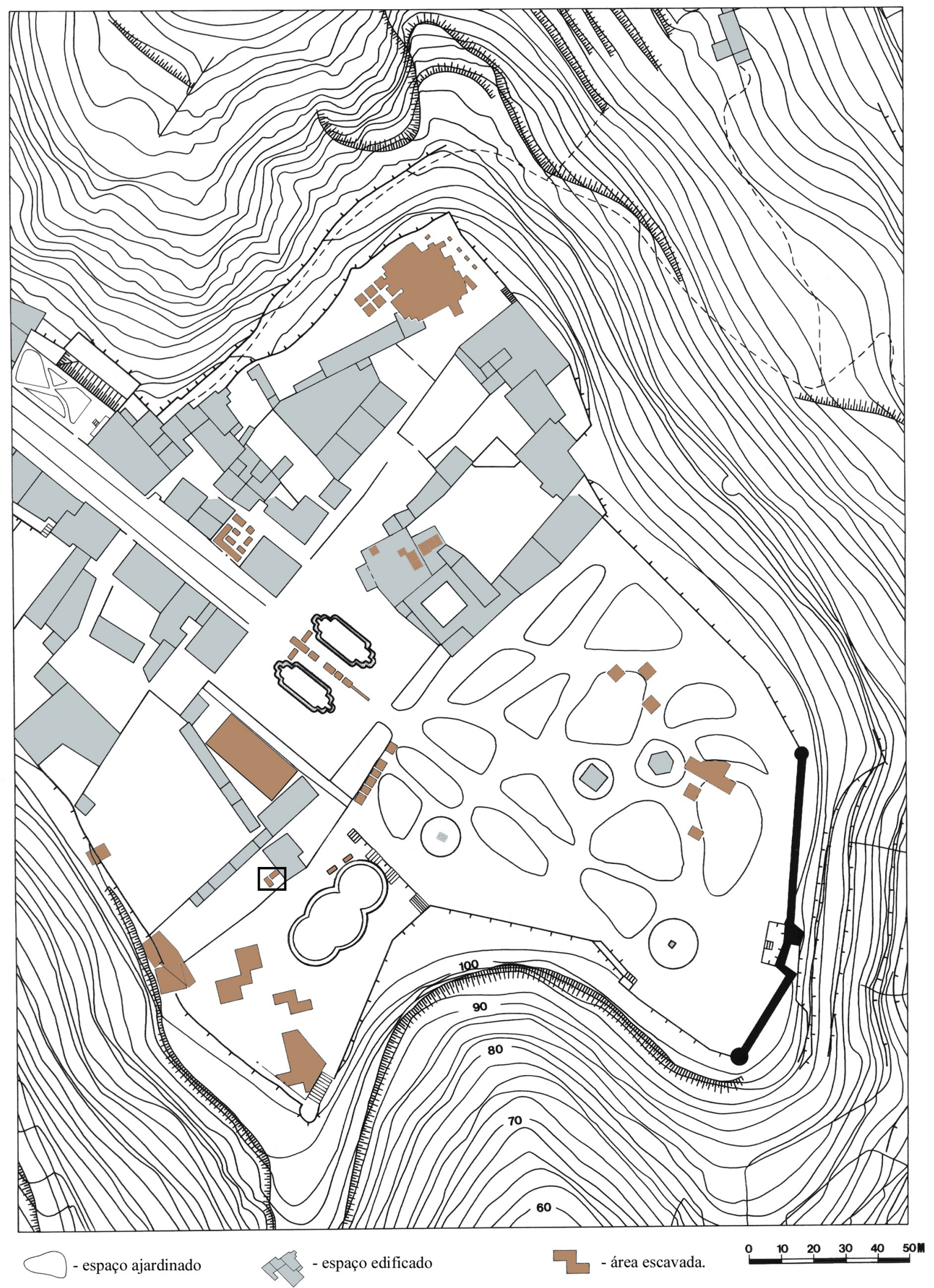

Fig. 2 - Localização das áreas intervencionadas na Alcáçova de Santarém (segundo Arruda, 2002; Viegas, 2003, modificado); no interior da quadrícula a negro, a área escavada em 2001. 


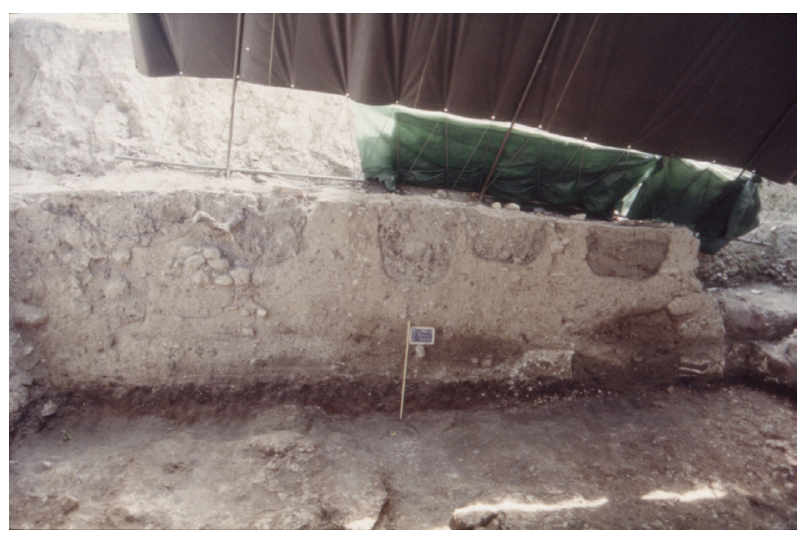

Fig. 3 - Fotografia do perfil oeste da área intervencionada.

diferentes diacronias, ainda que sempre centradas na primeira metade do $1^{o}$ milénio a.n.e. Cabe ainda referir que foi justamente nesta área que se documentaram, pela primeira vez, níveis conservados dos momentos finais da Idade do Bronze (Arruda e Sousa, 2015), situação que permite uma análise mais pormenorizada das alterações que se verificaram na transição entre esta fase e o período sidérico, sendo esta uma realidade raras vezes documentada no território actualmente português.

O conjunto artefactual recuperado na campanha de 2001 é francamente expressivo, totalizando 1086 fragmentos cerâmicos classificáveis (896 NMI), englobando ânforas, produções manuais, cinzentas, de engobe vermelho, cerâmicas pintadas, comuns e ainda outros artefactos de natureza diversa. Estes materiais são aqui integralmente estudados, optando-se pela sua caracterização de acordo com a respectiva fase de recolha, sendo posteriormente subdivididos por categoria (Fig. 4).

\section{FASE 1}

\subsection{Os elementos estratigráficos}

A primeira fase de ocupação da Idade do Ferro identificada na campanha de 2001, localizada imediatamente sobre os níveis do final da Idade do Bronze (Arruda e Sousa 2015), materializa-se num contexto de utilização primário formado por um pavimento de calcário moído e nódulos de argila alaranjados (U.E. [300]), onde se abriu uma vala, estreita e pouco profunda [301], eventualmente destinada ao escoamento de águas, bem como uma cavidade circular (buraco de poste?) (U.E. [303]) e outra de contornos mais irregulares [302]. Era delimitado a $\mathrm{N}$ por um muro [306] e a SW por restos de uma estrutura, possivelmente de taipa, infelizmente mal conservada (U.E.s [305], [334] e [335]). Associado a este espaço estaria também um pequeno empedrado ou soleira (U.E. [307]) (Fig. 5 e 6).

A este momento de ocupação pertence também uma vala (U.E.[293]), preenchida pelas U.E.s [288] e [289], nas quais foram recolhidos alguns restos osteológicos humanos (dentes e uma falange), sem conexão aparente. $\mathrm{O}$ abandono destes espaços é composto por diferentes estratos de derrube, constituídos maioritariamente por restos de taipa ou adobe (U.E.s [290], [291], [292], [295], [296], [297]).

\subsection{O conjunto artefactual}

Os materiais cerâmicos associados a esta primeira fase da ocupação são significativos, contando com 206 fragmentos inventariáveis (172 NMI). Distribuem-se pelas seguintes categorias: cerâmica manual $(69,20 \%)$, cinzenta $(18,60 \%)$, engobe vermelho $(5,23 \%)$, comum local regional $(3,49 \%)$, comum importada (oil bottle - 0,58\%), pintada $(1,74 \%)$ e outros artefactos $(1,16 \%)$.

\begin{tabular}{|l|c|c|c|c|c|c|c|c|c|c|}
\hline & Ânforas & $\begin{array}{l}\text { Comum } \\
\text { importada }\end{array}$ & $\begin{array}{l}\text { Engobe } \\
\text { vermelho }\end{array}$ & Cinzenta & Pintada & Comum & Manual & Outros & Intrusões & Total \\
\hline Fase 1 & 0 & 1 & 9 & 32 & 3 & 6 & 119 & 2 & 0 & 172 \\
\hline Fase 2 & 1 & 0 & 5 & 19 & 5 & 10 & 101 & 2 & 0 & 143 \\
\hline Fase 3 & 2 & 0 & 4 & 47 & 2 & 6 & 87 & 0 & 3 & 151 \\
\hline Fase 4 & 1 & 0 & 11 & 51 & 7 & 6 & 30 & 2 & 0 & 108 \\
\hline Fase 5 & 3 & 0 & 7 & 53 & 4 & 5 & 41 & 6 & 0 & 119 \\
\hline Fase 6 & 0 & 0 & 13 & 129 & 6 & 19 & 26 & 3 & 7 & 203 \\
\hline Total & 7 & 1 & 49 & 332 & 27 & 54 & 404 & 15 & 7 & 896 \\
\hline
\end{tabular}

Fig. 4 - Distribuição do conjunto artefactual por categoria e por fase (base NMI). 
Neste grupo, a cerâmica de produção manual é claramente maioritária, totalizando 139 fragmentos (119 NMI), dos quais a penas 15 (15 NMI) não permitiram uma classificação precisa.

Em termos formais, as formas abertas dominam o inventário, sendo o tipo mais bem representado a tigela (46 NMI - Fig. 14, no 37 a 68), de paredes côncavas ou rectilíneas. O bordo é normalmente simples e apenas em raras ocasiões apresenta um ligeiro espessamento interno (Fig. 14, $\mathrm{n}^{\mathrm{o}} 48$ ). Em alguns exemplares, observa-se também uma maior profundidade dos recipientes, conferida por uma maior verticalidade das suas paredes (Fig. 14, n. 52 a $55,60,63)$. Em outros raros casos, destacam-se as dimensões francamente reduzidas (Fig. 14, n. ${ }^{\mathbf{o}}$ $56,57)$, integrando vasos com pequena capacidade. Outros fragmentos com paredes mais convexas e oblíquas parecem também poder enquadrar-se nesta morfologia (Fig. 14, n. ${ }^{\circ}$ 61, 62), ainda que não se possa colocar de parte a possibilidade de corresponderem a pequenos vasos fechados. Por último, resta referir um exemplar (Fig. 14, n. ${ }^{\circ}$ 66) de dimensões superiores aos restantes, cujo bordo se encontra bem assinalado externamente. As superfícies de todos estes recipientes são cuidadosamente polidas, registando-se o alisamento em apenas cinco casos. A segunda forma mais bem representada engloba as taças carenadas (22 NMI - Fig. 13, nº 25 a 36). Os seus perfis são pouco variáveis, sendo a carena geralmente pouco assinalada, situando-se na zona superior da peça, e o bordo, esvertido, é de secção arredondada. As suas superfícies encontram-se invariavelmente bem polidas, sugerindo, tal como no caso anterior, uma utilização no âmbito do consumo de alimentos. No grupo das formas abertas de produção manual, deve ainda referir-se a identificação de dois outros exemplares (2 NMI - Fig. 15, n. $\left.{ }^{0} 75,76\right)$ com diâmetros amplos, paredes oblíquas e bordo bem assinalado na zona externa. Poderão corresponder a pratos, com superfícies alisadas ou polidas, devendo ainda acrescentar-se a presença de decoração incisa sobre o bordo de um dos fragmentos (Fig. 15, n. ${ }^{\circ} 75$ ).

As formas fechadas são um pouco menos expressivas em termos quantitativos. O tipo mais recorrente corresponde a vasos de perfil em S (20 NMI), de bordo esvertido e de secção simples, e colo geralmente curto e estrangulado, desenvolvendo-se num corpo de tendência ovalada. Alguns destes exemplares exibem paredes mais finas (Fig. 14, $\mathrm{n}^{\mathrm{o}}$ 69 a 74), podendo ter sido utilizados para o serviço

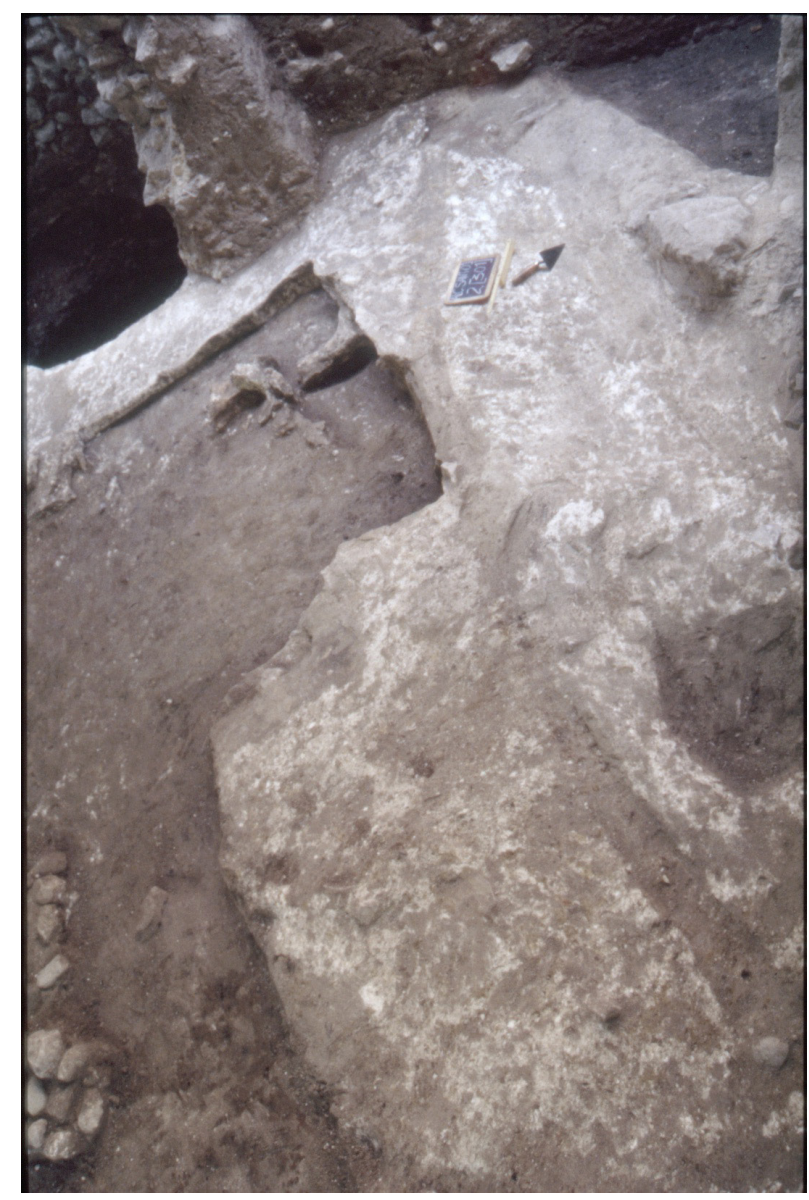

Fig. 5 - Fotografia do pavimento da Fase 1 (U.E. [300]).

de mesa. Outros são mais grosseiros, sugerindo um uso culinário ou para armazenamento (Fig. 15, n ${ }^{\circ}$ 78 a 80,82 a 84, 86). Em alguns raros casos, nota-se um ligeiro espessamento externo do bordo (Fig. 15, n. $\left.{ }^{\circ} 82,84,86\right)$. Deve ainda referir-se que, em algumas ocasiões (4 NMI), estas morfologias apresentam uma decoração incisa sobre o bordo (Fig. 15, n. ${ }^{0} 82$ a 84). Três exemplares, morfologicamente semelhantes a estes últimos (3 NMI - Fig. 15, n. ${ }^{\circ}$ $77,81,85)$, apresentam um diâmetro um pouco mais reduzido e um colo mais longo, características que sugerem uma utilização vocacionada para o armazenamento e serviço de líquidos, podendo também exibir decoração incisa na zona superior do bordo. Uma outra forma bem documentada no conjunto corresponde a potes de bordo de tendência vertical (8 NMI), de colo pouco assinalado, após o qual se desenvolve um corpo globular, com dimensões variáveis (Fig. 15, n. ${ }^{\circ} 87$ a 91, 96). As suas superfícies apresentam uma grande heterogeneida- 


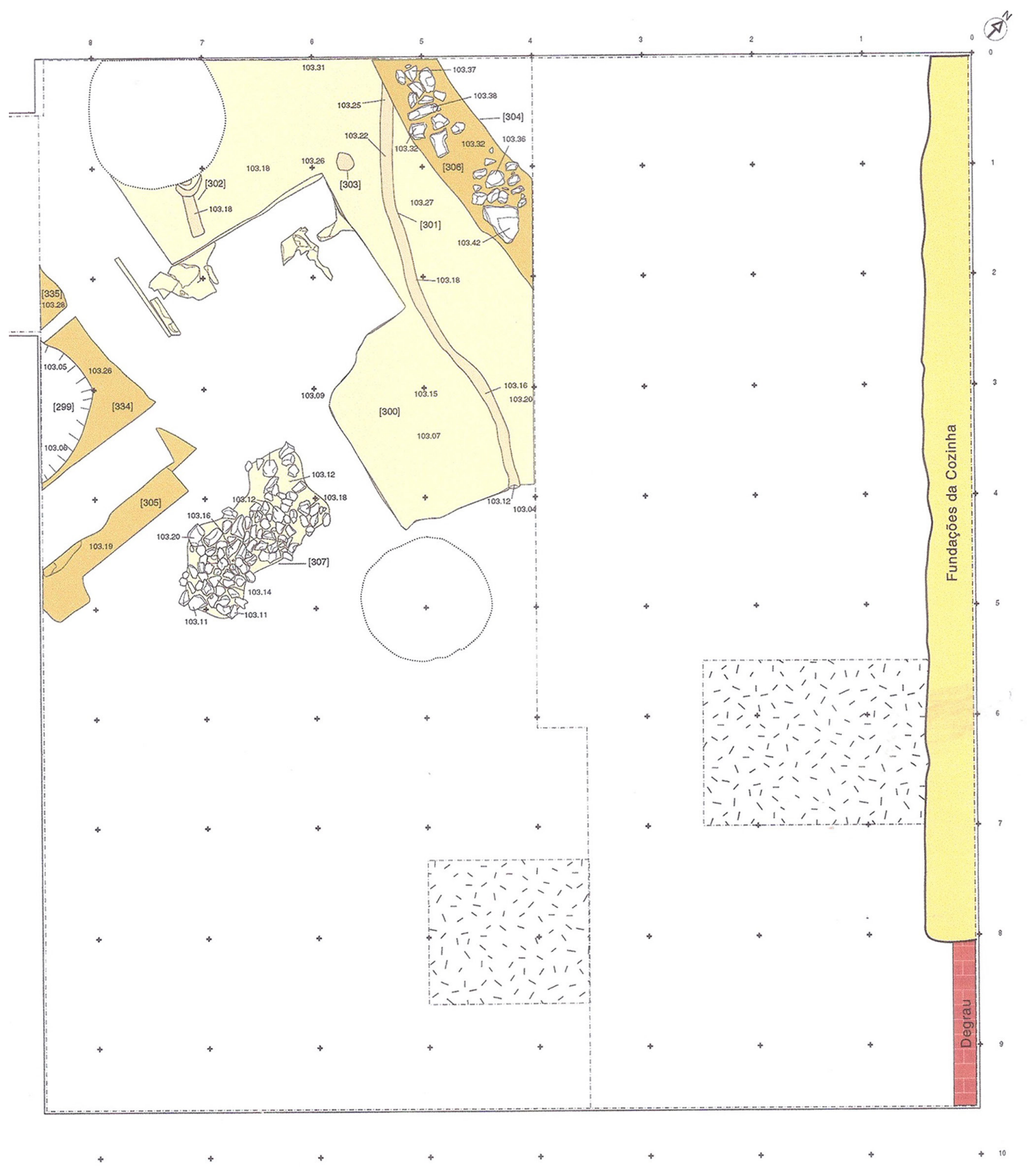

Fig. 6 - Planta da Fase 1. 
de de acabamentos, variando entre o polimento e o alisamento, podendo também não apresentar qualquer tratamento. A última forma identificada, pouco expressiva em termos quantitativos, corresponde a contentores esféricos de bordo invertido (3 NMI - Fig. 15, n.o 92, 93), cujas superfícies se encontram invariavelmente alisadas.

Em termos gerais, as formas de menor dimensão apresentam, normalmente, as superfícies polidas, o que poderá indiciar o seu uso no serviço de mesa enquanto que os vasos de maior tamanho exibem um menor cuidado ao nível do acabamento, sendo as suas superfícies apenas alisadas, apresentando-se, em raros casos, grosseiras, sugerindo uma funcionalidade orientada para o armazenamento ou confecção de alimentos.

No grupo da cerâmica manual contabilizaram-se ainda vários fundos, planos (oito exemplares Fig. 15, n. $.95,98,103$ ) ou ligeiramente convexos (quatro exemplares - Fig. 15, n. ${ }^{\circ}$ 94, 99, 100, 104), sendo mais raros os em ônfalo (um exemplar - Fig. 15, n. ${ }^{\circ}$ 97). Algumas paredes estão decoradas. Uma delas apresenta um cordão plástico sobre o qual são visíveis incisões oblíquas (Fig. 15, n. ${ }^{\circ} 101$ ); outras quatro possuem vestígios de pintura vermelha e branca, aplicada em superfícies cuidadosamente polidas, não sendo de descartar a possibilidade de integrarem algumas das formas abertas anteriormente descritas. Infelizmente, estes vestígios de pintura são muito ténues, não permitindo a sua representação gráfica.

No conjunto dos materiais a torno que exibem características orientalizantes, destaca-se um pequeno fragmento de fundo (1 NMI - Fig. 13, n. $\left.{ }^{\circ} 1\right)$, de difícil classificação, mas que poderá eventualmente corresponder ao fundo de uma oil bottle. As características da sua pasta, concretamente a presença de elementos não plásticos de tonalidade escura que podem ser partículas de xisto, sugerem uma origem exógena, eventualmente da costa de Málaga.

A cerâmica de engobe vermelho engloba 11 fragmentos (9 NMI), três dos quais inclassificáveis (3 $\mathrm{NMI}$ ), sendo os pratos (6 NMI) a morfologia dominante (Fig. 13, n. $\left.{ }^{\circ} 3,4\right)$. No entanto, apenas um destes exemplares (Fig. 13, n.o 4) possibilitou o cálculo da largura do bordo $(4,67 \mathrm{~cm}$ - diâmetro total de $26,67 \mathrm{~cm}$ ), que permite a sua aproximação ao grupo P2 definido por Rufete Tomico (1988-1989). Outros fragmentos de carena (Fig. 13, n. ${ }^{\circ}$ 2) e um fundo convexo com pé ligeiramente destacado (Fig.
13, n. ${ }^{0}$ 5) poderão também corresponder a idêntica morfologia.

Vasos pintados em bandas são também escassos nesta fase, contando com apenas três fragmentos (3 NMI). Destes, dois (2 NMI) pertencem a pithoi decorados com bandas vermelhas, sendo o único exemplar passível de representação gráfica (Fig. 13, n. ${ }^{\circ}$ ) de bordo esvertido e lábio pendente, colo curto de paredes verticais, encontrando-se bem assinalada a sua separação com o restante corpo, por um ressalto. Por último, cabe referir um outro fragmento (1 NMI - Fig. 13, n. ${ }^{\circ}$ 6) que parece corresponder a uma forma fechada, apresentando um colo vertical e um bordo assinalado na área externa. Poderá, eventualmente, corresponder a uma urna tipo Cruz del Negro.

A cerâmica cinzenta está bem documentada, com 42 fragmentos (32 NMI), seis dos quais inclassificáveis (6 NMI), sendo as suas superfícies invariavelmente polidas. A forma mais recorrente corresponde a tigelas de perfil semi-hemisférico (19 NMI), de bordo simples (Fig. 13, n. ${ }^{\circ}$ 9), mas sobretudo engrossado internamente (Fig. 13, n. ${ }^{\circ} 8,10$, 11). Deve ainda referir-se que um destes exemplares (Fig. 13, n. ${ }^{\circ}$ 11) apresenta sulcos incisos na superfície interna, apesar da sua reduzida dimensão não permitir uma leitura clara do motivo decorativo de que fariam parte. As restantes morfologias de cerâmica cinzenta são menos frequentes, integrando taças (4 NMI) de perfil ligeiramente carenado (Fig. 13, n. ${ }^{\circ}$ 12), ou com bordo assinalado, de paredes oblíquas (Fig. 13, n.. 13) ou verticais (Fig. 13, n.o 14). Por último, deve referir-se a presença de pratos (3 NMI) de lábio curto e pouco assinalado (Fig. 13, n. ${ }^{\circ}$ 15), possivelmente inspirado nas produções de engobe vermelho. Nesta categoria, contabilizaram-se ainda vários fragmentos de fundo, planos (sete exemplares - Fig. 13, n. ${ }^{\circ}$ 18, 19, 21) ou ligeiramente convexos (1 exemplar - Fig. 13, n. $\left.{ }^{\circ} 20\right)$, um dos quais com sulcos incisos na superfície interna (Fig. 13, n. ${ }^{\circ} 18$ ), uma asa de secção bífida (Fig. 13, n. ${ }^{\circ}$ 17) e um fragmento de parede com sulcos brunidos na superfície interna (Fig. 13, n. ${ }^{\circ}$ 16).

A cerâmica comum a torno conta com sete fragmentos (6 NMI), um dos quais inclassificável (1 NMI). Em termos formais, correspondem a tigelas de perfil hemisférico (2 NMI), de bordo ligeiramente engrossado e superfícies polidas (Fig. 13, n. $\left.{ }^{\circ} 22\right)$ e a vasos de perfil em S (3 NMI - Fig. 13, n. $\left.{ }^{\circ} 23\right)$, possivelmente utilizados para a confecção de alimentos. Deve referir-se ainda a recolha de um 
fundo convexo (Fig. 13, n. $\left.{ }^{\circ} 24\right)$, provavelmente pertencente a um destes últimos, e de uma asa de secção bífida.

Ao conjunto artefactual associado a esta primeira fase de ocupação da Idade do Ferro pertence ainda uma pequena peça de jogo (1 NMI), que aproveitou um fragmento de cerâmica comum, e dois fragmentos com paredes espessas e grosseiras que estão perfuradas (1 NMI - Fig. 15, n.. 102), e que fariam possivelmente parte de copelas relacionadas com actividades metalúrgicas.

\subsection{Discussão e apreciação cronológica}

O conjunto recuperado nesta primeira fase associável à ocupação da Idade do Ferro da Alcáçova de Santarém é significativo, ainda que seja composto por um número reduzido de exemplares que proporcionem uma indicação cronológica mais precisa. Entre estes, destaca-se, sem dúvida, o prato de engobe vermelho assimilável ao tipo P2 que, na área de Huelva, surge apenas a partir de finais do século VIII a.C. (Rufete Tomico 1988-1989: 27). Entre os materiais de cariz orientalizante deve ainda realçar-se o pithos, cujas características morfológicas, em concreto o ressalto que separa o colo do corpo da peça, sugere uma cronologia centrada no século VII a.C. (Torres Ortíz 2002: 150), na qual se poderá também integrar o possível fragmento de urna tipo Cruz del Negro e a oil bottle (Aubet 1976-1978: 275).

Considerando os elementos anteriormente expostos, bem como o facto de os níveis arqueológicos associados a esta fase se sobreporem directamente aos do Bronze final (Arruda e Sousa 2015) pensamos ser admissível uma cronologia tradicional centrada entre os finais do século VIII e os inícios do século VII a.n.e. para esta primeira ocupação sidérica.

É importante ainda salientar a expressividade das produções manuais durante este momento $(69,19 \%$ do conjunto) e sublinhar que, quer em termos morfológicos quer da sua distribuição quantitativa, se mantêm as mesmas tendências verificadas no horizonte do Bronze Final (ibidem). Não só se produziam as mesmas morfologias como também as mesmas quantidades, situação que indica poucas alterações em termos dos hábitos quotidianos da comunidade que habitou a Alcáçova de Santarém nos alvores da Idade do Ferro. Com efeito, as únicas modificações que se verificaram entre estes dois momentos aconteceram no âmbito decorativo, com o desaparecimento total dos motivos inspirados no mundo mesetenho, que eram bastante expressivos durante o final da Idade do Bronze, mantendo-se apenas a utilização da incisão, geralmente sobre o bordo. As decorações brunidas, que ocorriam também durante o Bronze Final, mantiveram-se durante esta primeira fase da Idade do Ferro, ainda que, no conjunto analisado, tenham sido apenas documentadas em cerâmica cinzenta a torno.

Ainda que a introdução de artefactos cerâmicos de matriz orientalizante tenha gerado, seguramente, um forte impacto cultural, não acarretou, pelo menos durante estes momentos iniciais da Idade do Ferro, alterações significativas no quadro das produções tradicionais autóctones. Com efeito, a única alteração que pudemos detectar no âmbito das produções manuais é a introdução de decoração pintada, em tons de vermelho e branco, na superfície de algumas formas abertas. Este fenómeno poderá relacionar-se, mais uma vez, com influências das zonas mais interiores do território peninsular, em concreto com o horizonte das cerâmicas de estilo Medellín, não podendo, contudo, excluir-se a possibilidade de ser um fenómeno de origem local, resultante do contacto com novas tecnologias e tendências decorativas introduzidas pelo "pacote" artefactual orientalizante.

Por último, é importante ainda salientar a presença, logo neste primeiro momento, de fragmentos cerâmicos com as paredes perfuradas que se podem relacionar com actividades metalúrgicas, muito concretamente a copelação da prata. A sua ausência no repertório do Bronze Final sugere alterações significativas nas estratégias económicas e produtivas que emergem nos alvores do período sidérico na Alcáçova de Santarém.

\section{FASE 2}

\subsection{Os elementos estratigráficos}

O momento de ocupação que se sobrepõe à fase anterior é constituído por um novo nível de pavimento, neste caso de argilas em tons laranja-amarelados (U.E. [285]=[286]), que está associado a duas pequenas fossas (U.E.s [284] - enchimento U.E. [283] - e [299] - enchimento [298]) (Fig. 7 e 8). Num período relativamente curto, este espaço terá sido remodelado com a construção de um novo piso (U.E. [272]), desta vez construído com argilas amareladas e nódulos de caliça, associado a uma estrutura de combustão (U.E. [273]), com cerca de 1,5 $\mathrm{m}$ de comprimento, mas infelizmente mal conservada, e a uma pequena fossa (U.E. [282] - en- 
chimento U.E. [281]). Os dois níveis de pavimento encontram-se separados por apenas um pequeno estrato de aterro (U.E. [279]), que terá servido de preparação para o piso mais recente.

\subsection{O conjunto artefactual}

O espólio associado a esta segunda fase é um pouco menos numeroso que o anterior, englobando 166 fragmentos inventariáveis (143 NMI), que se dividem por: cerâmica manual $(70,62 \%)$, ânforas $(0,70 \%)$, cerâmica cinzenta $(13,29 \%)$, cerâmica de engobe vermelho $(3,50 \%)$, cerâmica comum $(6,99 \%)$, cerâmica pintada $(3,50 \%)$ e outros artefactos $(1,40 \%)$.

Uma vez mais, a cerâmica manual é maioritária, com 113 fragmentos (101 NMI), dos quais apenas 11 (11 NMI) são inclassificáveis. As formas mais bem representadas enquadram-se em tipos abertos, em concreto nas taças carenadas (33 NMI - Fig. 16 e $17, \mathrm{n}^{\mathrm{o}} 130$ a 142) e tigelas (31 NMI - Fig. 17, n⿳0 143 a 160), com características semelhantes às descritas na fase anterior. Cabe apenas destacar, entre estas as últimas, um exemplar com uma pequena aba junto ao bordo (Fig. 17, n. ${ }^{0} 159$ ), que possivelmente auxiliaria a preensão do recipiente, dois outros casos que exibem dimensões superiores aos restantes, de bordo assinalado (Fig. 17, n. ${ }^{\circ} 160$ ), e ainda um vaso com vestígios de pintura de decoração sobre-pintada vermelha e branca em ambas as superfícies (Fig. 17 , n. $\left.{ }^{\circ} 145\right)$. As superfícies destas formas demonstram, na sua esmagadora maioria, um polimento cuidado, registando-se o alisamento em apenas três ocasiões. No conjunto das formas abertas, registou-se ainda, e tal como na fase anterior, a presença de dois recipientes de tipo prato (2 NMI), de superfícies alisadas e polidas, com diâmetro largo, paredes oblíquas e bordo assinalado (Fig. 17, n. ${ }^{\circ}$ 161).

Entre as formas fechadas, menos abundantes, contam-se vários recipientes de perfil em S (19 NMI - Fig. 17, no 162 a 166, 169 a 171, 173 a 175, 177), de bordo esvertido e colo geralmente curto, dois dos quais com incisões na área superior (Fig. 17, n. ${ }^{\circ}$ 174, 175). Um destes vasos exibe ainda um diâmetro consideravelmente mais amplo que os restantes (Fig. 17, n. $\left.{ }^{\circ} 177\right)$. Em outros três casos (3 NMI - Fig. 17, n.․ 167, 168 e 172), o colo é mais desenvolvido podendo indiciar, tal como ocorre na Fase 1, a existência de vasos consentâneos com a contenção e serviço de líquidos. Por último, cabe também referir a identificação de um recipiente de bordo curto e de tendência vertical, decorado com

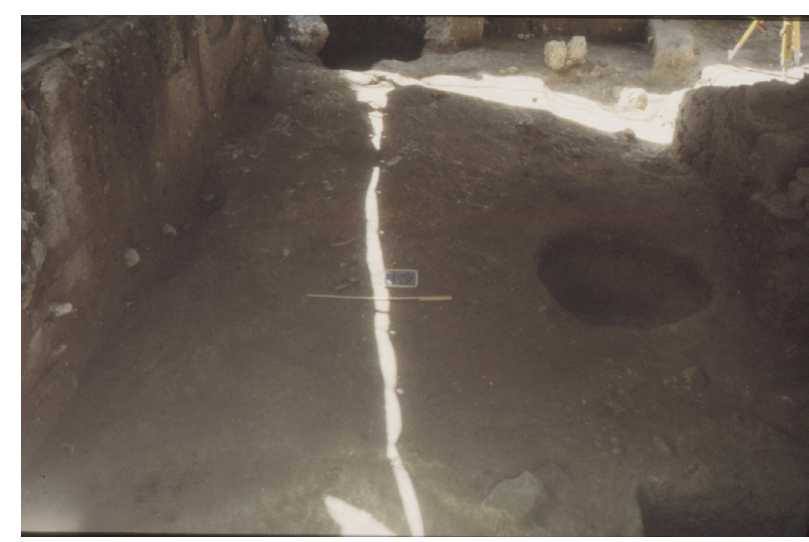

Fig. 7 - Fotografia do pavimento da Fase 2 (U.E. [285=286]).

incisões no bordo (1 NMI - Fig. 17, n. ${ }^{\circ}$ 166). As superfícies destes exemplares são geralmente alisadas, registando-se o polimento em raras ocasiões.

Nesta categoria registaram-se ainda alguns fundos, sendo a maioria de base aplanada (seis exemplares) e apenas um em ônfalo. Recolheram-se ainda fragmentos de parede, dois dos quais com vestígios de decoração sobre-pintada vermelha e branca em ambas as superfícies, sendo visível em um deles um motivo quadrangular que limita um outro de formato circular (Fig. 17, n. ${ }^{\circ}$ 178). Por fim, destaca-se ainda um outro fragmento decorado através de digitações (Fig. 17, n. ${ }^{\circ}$ 176).

As ânforas encontram-se escassamente representadas, contando com apenas dois fragmentos (1 NMI - Fig. 16, n. 105), sendo o único elemento de bordo integrável no tipo 10.1.2.1 de Ramon Torres, provavelmente proveniente da costa de Málaga, considerando a presença de partículas escuras que parecem corresponder a xistos.

A cerâmica de engobe vermelho totaliza apenas sete fragmentos ( $5 \mathrm{NMI})$, sendo, uma vez mais, o prato a morfologia dominante (4 NMI - Fig. 16, n. ${ }^{\circ} 107$ a 109). O estado de fragmentação dos exemplares permitiu a medição da largura do bordo em um único caso (Fig. 16, n. ${ }^{\circ} 108$ ), tendo este $3,3 \mathrm{~cm}$, sendo o diâmetro total de $22,5 \mathrm{~cm}$, aproximando-se da forma P1 de Rufete Tomico (1988-1989). Em um outro caso (Fig. 16, n.o 109), destaca-se ainda a presença de um lábio ligeiramente pendente. A única outra forma representada (1 NMI) corresponde, provavelmente, a um pequeno vaso de bordo simples e esvertido, não sendo, contudo, de excluir a possibilidade de corresponder a parte de um pequeno suporte (Fig. 16, n. ${ }^{\circ}$ 106). 


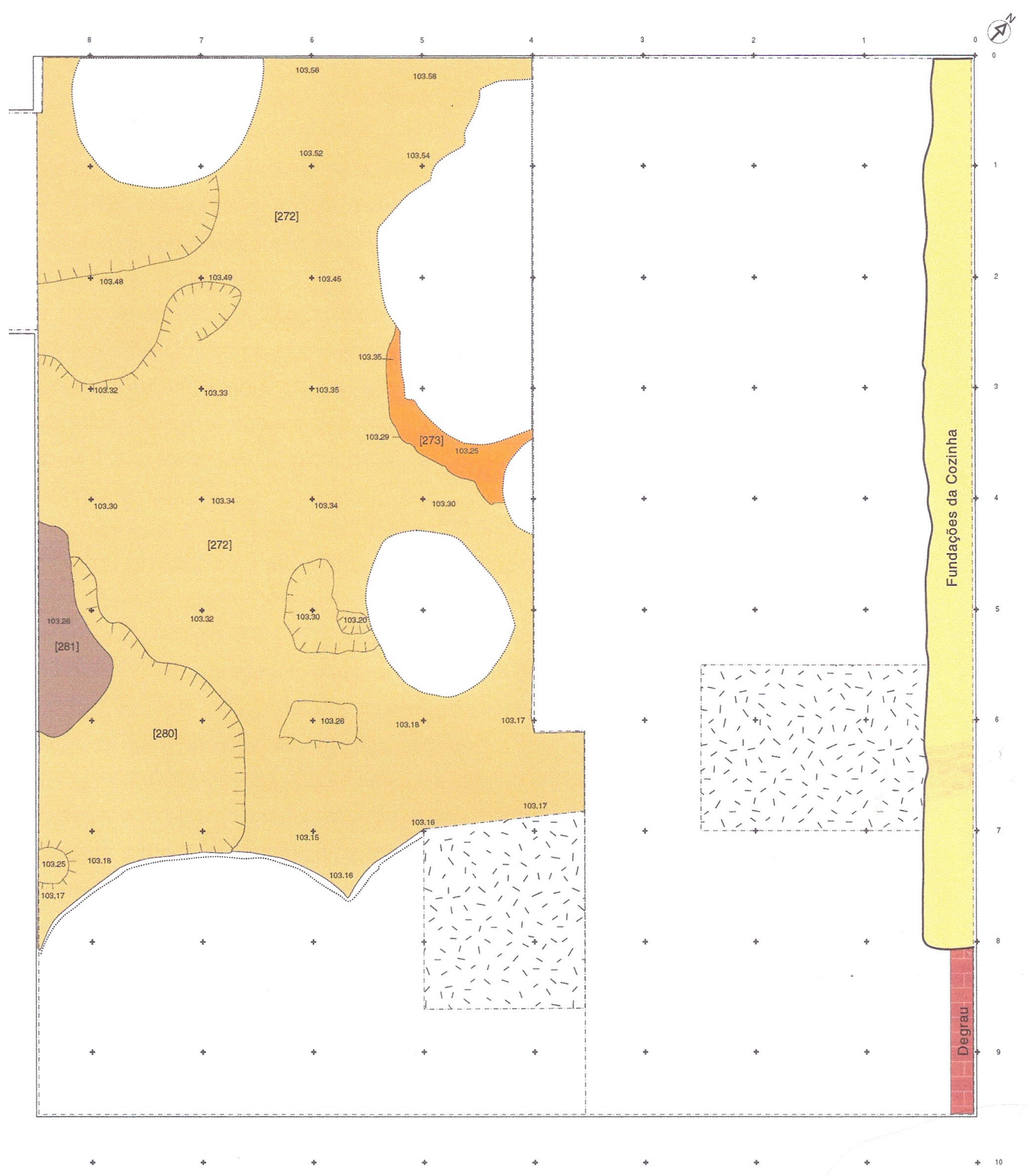

Fig. 8 - Planta do momento mais antigo da Fase 2. 
Grandes recipientes pintados em bandas surgem, uma vez mais, no conjunto da Fase 2, correspondendo exclusivamente a pithoi (5 NMI - Fig. 16, n. .0110 e 111). Os exemplares mais bem conservados exibem bordos esvertidos e colos de tendência vertical (Fig. 16, n. ${ }^{\circ}$ 110) ou ligeiramente oblíqua (Fig. 16, n. $\left.{ }^{\circ} 111\right)$. A esta mesma forma deverão pertencer ainda vários fragmentos de parede com decoração pintada em bandas (Fig. 16, n. ${ }^{\circ} 112$ ).

A cerâmica cinzenta está representada por 21 fragmentos (19 NMI), dois dos quais inclassificáveis ( $2 \mathrm{NMI})$, todos com superfícies bem polidas. A forma dominante integra as tigelas (14 NMI) de perfil hemisférico, de bordo engrossado (Fig. 16, n. ${ }^{\circ}$ 113 a 115, 117 a 119), ou, mais raramente, apontado (Fig. 16, n. ${ }^{\circ} 116$ ). Uma destas peças exibe uma decoração incisa na superfície interna, ainda que o motivo representado não seja claro (Fig. 16, n. ${ }^{0}$ 115). Este conjunto conta também com uma taça de perfil carenado (1 NMI - Fig. 16, n. $\left.{ }^{\circ} 120\right)$ e pratos (2 NMI) de bordo simples (Fig. 16, n. ${ }^{\circ} 121$ ) ou com lábio curto e pouco assinalado (Fig. 16, n. ${ }^{\circ}$ 122), sendo estes possivelmente inspirados nas produções de engobe vermelho. Entre a cerâmica cinzenta desta Fase 2 identificou-se ainda um fragmento de fundo aplanado com pé destacado (Fig. 16, n. ${ }^{\circ} 123$ ) e um fragmento de carena.

A cerâmica comum a torno está representada por 12 fragmentos (10 NMI), integrando tigelas (3 NMI) com superfícies polidas, de perfil hemisférico e bordo engrossado internamente e, sobretudo, vasos fechados de perfil em S (6 NMI - Fig. 16, n. ${ }^{\circ}$ 124 a 128). Destaca-se ainda um exemplar (1 NMI) de bordo esvertido e engrossado (Fig. 16, n. ${ }^{0} 129$ ), coberto por engobe branco na superfície externa, que se integra com facilidade no tipo $10 \mathrm{Bb}$ definido para a Rua dos Correeiros (Sousa 2014).

Tal como na fase anterior, também entre este conjunto se recuperou um fragmento de bordo de um pequeno vaso de superfícies grosseiras (1 NMI - Fig. 17, n. ${ }^{0} 179$ ) que poderá corresponder a um utensílio relacionado com a produção metalúrgica.

Por último, deve ainda destacar-se a recolha de uma conta de colar de pasta vítrea, de cor azul claro, ainda que esta tonalidade se possa dever à sua forte irisação (Fig. 9).

\subsection{Discussão e apreciação cronológica}

Os artefactos associados a esta segunda fase da ocupação da Idade do Ferro não variam, de forma

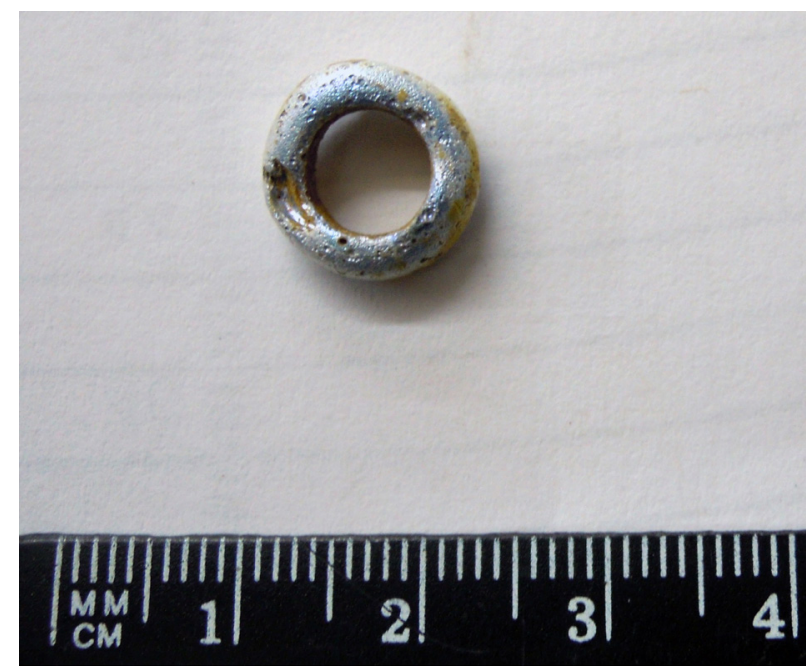

Fig. 9 - Conta de colar de pasta vítrea da Fase 2.

significativa, da realidade registada no momento anterior, mesmo em termos percentuais.

No conjunto da cerâmica manual, a única diferença observável corresponde à ausência de vasos de perfil esférico que, com efeito, desaparecem a partir deste momento do repertório morfológico da Alcáçova de Santarém. Contudo, as restantes tendências, verificadas quer em termos morfológicos, quer em termos decorativos, coincidem com a situação descrita para a Fase 1.

É sobretudo no conjunto de materiais de matriz orientalizante que se verificam algumas diferenças, ainda que apenas pontuais. É a este segundo momento que se pode associar o mais antigo fragmento de ânfora recolhido na estratigrafia de 2001, integrável no tipo 10.1.2.1 de Ramon Torres, para o qual se propõe uma baliza de produção centrada entre o segundo quartel do século VII e os meados do século VI a.n.e. (Ramon Torres 1995: 231). No conjunto de cerâmica de engobe vermelho destaca-se a identificação de um exemplar integrável no tipo P1 de Rufete Tomico, cuja perduração em horizontes dos séculos VII e VI a.n.e. se encontra amplamente documentada na costa andaluza (Rufete Tomico 1988-1989). Os restantes materiais, em concreto os pithoi pintados e as formas de cerâmica cinzenta, são também compatíveis com uma cronologia centrada na primeira metade do século VII a.n.e., momento no qual se pode integrar esta segunda fase.

Em termos do repertório morfológico deve ainda assinalar-se a introdução, durante este momento, de taças carenadas nas produções cinzentas, 
situação que se poderá justificar pelo sucesso desta forma no âmbito das manufacturas locais.

Por último, resta sublinhar que as evidências possivelmente relacionadas com actividades metalúrgicas continuam presentes no conjunto.

\section{FASE 3}

\subsection{Os elementos estratigráficos}

A fase que se segue ao momento anterior parece corresponder a um período intermédio, caracterizado pela deposição de vários estratos de aterro (U.E.s [270], [258], [274], [267=269]), pontualmente utilizados com solo de ocupação, e aos quais se pôde associar uma fossa (U.E.s [280=325] - enchimento $[257=271])$. Trata-se, muito provavelmente, do momento de preparação para a construção da fase seguinte.

\subsection{O conjunto artefactual}

Os materiais recolhidos nesta terceira fase da ocupação da Idade do Ferro totalizam 181 fragmentos classificáveis (151 NMI). No entanto, quatro destes (3 NMI - 1,99\% do conjunto) correspondem seguramente a intrusões de períodos posteriores. Os restantes dividem-se pelas seguintes categorias: cerâmica manual $(57,62 \%)$, ânforas $(1,32 \%)$, cinzenta $(31,13 \%)$, engobe vermelho $(2,65 \%)$, comum $(3,97 \%)$ e pintada $(1,32 \%)$.

A cerâmica manual continua a ser a produção mais abundante, com 99 fragmentos (87 NMI), oito dos quais ( $8 \mathrm{NMI}$ ) inclassificáveis. Esta categoria segue sendo dominada pelas taças carenadas (15 NMI - Fig. 18 e 19, no 214 a 217, 219, 222, 245), uma das quais decorada com engobe vermelho na zona superior do bordo (Fig. 19, n. ${ }^{\circ}$ 245), e, sobretudo, pelas tigelas (41 NMI - Fig. 18 e 19, no 218, 223 a 237,241 a 244). Entre estas, contam-se alguns exemplares de bordo assinalado (Fig. 18 e 19, n. ${ }^{\mathrm{o}}$ 218, 223, 224, 237, 241), sendo, contudo, a maioria de perfil simples. Quatro destes recipientes (Fig. 19, n. ${ }^{0} 226$ a 229) exibem ainda vestígios de decoração sobre-pintada branca e vermelha nas suas superfícies, e um outro (Fig. 19, n. ${ }^{\circ}$ 244) sulcos brunidos na superfície interna. Entre as formas abertas estão ainda presentes dois fragmentos de pratos (2 NMI), sendo de realçar que em um destes exemplares foi aplicado um engobe vermelho em ambas as superfícies (Fig. 19, n. $\left.{ }^{\circ} 246\right)$.

Três peças (3 NMI - Fig. 19, n. ${ }^{\circ} 238$ a 240) deixam algumas dúvidas sobre a sua classificação tipológica, uma vez que a curvatura acentuada das suas paredes sugere a correspondência a pequenos vasos fechados, eventualmente utilizados para o consumo de líquidos.

As formas fechadas são dominadas pelos vasos de perfil em S (17 NMI - Fig. 19, n. ${ }^{\circ} 247$ a 257), ostentando dois deles decorações incisas, sobre o bordo (Fig. 19, n. . 255) ou sobre o colo (Fig. 19, n. ${ }^{\mathrm{o}}$ 256), e um outro um cordão plástico na área superior do corpo (Fig. 19, n. ${ }^{\circ} 257$ ). Resta ainda referir a identificação de um exemplar com diâmetro amplo e paredes oblíquas que poderá corresponder a um vaso "à chardon" (Fig. 19, n. ․ 258).

Entre este conjunto, identificou-se ainda uma asa de secção oval, uma parede com decoração incisa de difícil leitura (Fig. 19, n. ${ }^{\circ}$ 264), uma outra onde foi aplicado um cordão plástico na superfície externa (Fig. 19, n. . 265), e ainda uma última com vestígios de decoração sobre-pintada branca e vermelha. Registaram-se também cinco bases planas (Fig. 19, n. ${ }^{\circ} 260$ a 262), dois fundos convexos com pé destacado (Fig. 19, n. ${ }^{\circ}$ 263) e um outro em ônfalo (Fig. 19, n. $\left.{ }^{\circ} 259\right)$.

Os contentores anfóricos permanecem pouco expressivos, contando com apenas dois exemplares (2 NMI). Destes, apenas um permitiu uma classificação tipológica (Fig. 18, n. ${ }^{0}$ 180), correspondendo ao tipo 10.1.2.1 de Ramon Torres, possivelmente importado da área de Málaga, considerando a presença de partículas de xisto.

A cerâmica de engobe vermelho está representada por cinco fragmentos (4 NMI), todos eles correspondentes a pratos (Fig. 18, n. ${ }^{\circ} 181$ a 183). O exemplar mais bem conservado (Fig. 18, n. ${ }^{\mathrm{o}}$ 181) tem um diâmetro total de $22 \mathrm{~cm}$ e uma largura de bordo de $4,6 \mathrm{~cm}$, o que permite a sua aproximação ao tipo P2 de Rufete Tomico (1988-1989).

A cerâmica pintada em bandas está representada, uma vez mais, apenas por pithos (2 NMI - Fig. 18, n. .0 184) de bordo esvertido e colo de tendência vertical. A estes recipientes serão provavelmente pertencentes os diversos fragmentos de paredes pintadas em bandas vermelhas e negras (Fig. 18, n. ${ }^{\circ} 185$ e 186) e também um fragmento de asa de secção bífida.

A cerâmica cinzenta conta com 55 exemplares (47 NMI), cinco dos quais (5 NMI) inclassificáveis. A forma dominante é, uma vez mais, a tigela (39 NMI), de perfil hemisférico, com bordo simples ou engrossado (Fig. 18, n. . 187 a 195). Outras peças semelhantes, mas com dimensões bem mais reduzidas, estão também presentes no conjunto estudado (Fig. 18, n. ${ }^{\circ}$ 196), podendo apresentar paredes mais 
oblíquas (Fig. 18, n. . 197) ou mais verticais (Fig. 18, n. 198 e 199). Dois outros exemplares correspondem a taças, sendo uma de perfil carenado (1 NMI - Fig. 18, n. $\left.{ }^{\circ} 200\right)$ e a outra de bordo esvertido e aplanado (1 NMI - Fig. 18, n. ${ }^{\circ}$ 201), na qual foi aplicado um engobe cinzento escuro. Nas formas abertas, conta-se ainda um bordo de prato (1 NMI - Fig. 18, n. 202), de lábio curto e aplanado, possivelmente inspirado, tal como nos casos anteriores, nas produções de engobe vermelho. Entre a cerâmica cinzenta desta fase identificou-se também seis fragmentos de bases aplanadas (Fig. 18, $\mathrm{n}^{\circ}$ 204, 206 a 209), que podem, por vezes, apresentar um pé destacado (Fig. 18, n. ${ }^{\circ}$ 205), uma carena e ainda um exemplar decorado na superfície interna (Fig. 18, n. ${ }^{\circ} 203$ ) cujo motivo parece assemelhar-se a uma sequência de flores de lótus estilizadas.

A cerâmica comum a torno está representada por 9 fragmentos (6 NMI), um dos quais (1 NMI) inclassificável. A única forma identificada corresponde a vasos de perfil em S (5 NMI - Fig. 18, n. ${ }^{\circ}$ 210 a 212). Neste conjunto, recolheram-se duas bases aplanadas (Fig. 18, n. ${ }^{\circ}$ 213, 220) e ainda um fragmento decorado com incisões na superfície interna (Fig. 18, n. ${ }^{\circ}$ 221) não sendo, infelizmente, possível discriminar o motivo representado.

\subsection{Discussão e apreciação cronológica}

$\mathrm{O}$ conjunto artefactual da Fase 3 mantêm claras continuidades com os registados anteriormente manifestando, contudo, algumas diferenças que podem ser significativas.

Em primeiro lugar, e numa perspectiva global, verifica-se uma ligeira diminuição da percentagem das produções manuais em detrimento do acréscimo das cerâmicas cinzentas, uma tendência que se irá acentuar durante as fases subsequentes.

Em termos mais específicos, é possível notar também ligeiras alterações nos repertórios morfológicos de algumas categorias. Nas produções manuais, destaca-se o aparecimento de duas novas morfologias. A primeira parece corresponder a pequenos vasos fechados, possivelmente utilizados no serviço de mesa para o consumo de líquidos, e a segunda integra os vasos "à chardon", utilizados eventualmente para armazenamento. Outras diferenças do âmbito decorativo devem ter também assinaladas, nomeadamente a presença de dois exemplares nos quais foram aplicadas faixas de engobe vermelho, situação facilmente relacionável com a influência de decorações de cariz mais orientalizan- te. Por outro lado, nas produções cinzentas surge uma nova forma de taça, com bordo esvertido e aplanado, na qual foi aplicada um engobe cinzento escuro, que recorda também, em termos morfológicos, as produções de engobe vermelho.

O conjunto da Fase 3 é muito difícil de diferenciar, em termos cronológicos, do momento antecedente. Com efeito, permanecem as mesmas morfologias orientalizantes (ânforas do tipo 10.1.2.1 de Ramon Torres, pratos do tipo P2 de Rufete Tomico e pithoi), situação que dificulta a distinção entre as ambas as fases. Considerando, contudo, a cronologia relativa, pensamos ser coerente propor um momento centrado entre os finais da primeira metade e os finais do século VII a.n.e. para esta terceira fase.

\section{FASE 4}

\subsection{Os elementos estratigráficos}

O momento que se sucede corresponde a um ambiente formado pelas estruturas (U.E. [252], [253] e [268] ), que podem ter feito parte de uma célula de uma unidade habitacional, e por construções de taipa e de adobe, que provavelmente pertenceriam a um piso e seus apoios (U.E.s [260] a [266]) (Fig. 10). A este espaço podem ainda associar-se quatro buracos de poste (U.E.s [337], [265], [264], [261]). Num momento um pouco posterior, este ambiente terá sido remodelado com a construção de um outro pavimento (U.E.s $[249=251=256]$ ), ao qual estava associada uma estrutura de combustão(U.E. [255]), sob a qual se identificou um nível de aterro (U.E. [259]). O abandono deste ambiente está representado, por sua vez, pelos estratos de derrube e aterro [242], [248], [253] e [254].

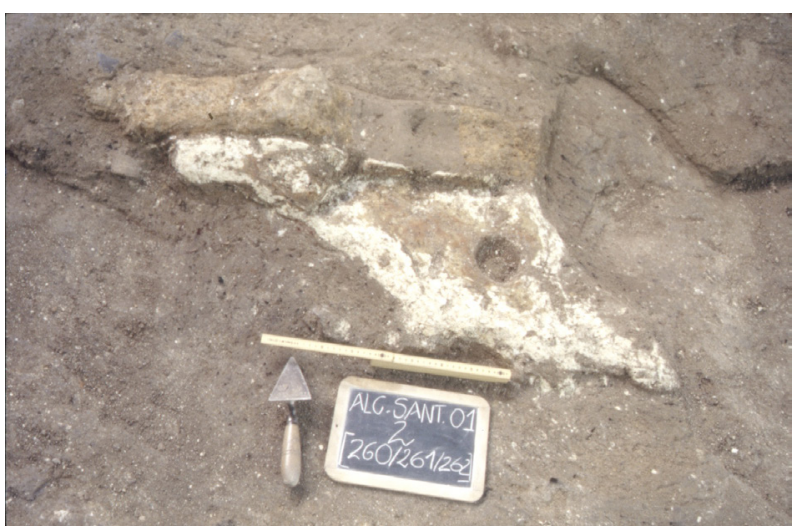

Fig. 10 - Fotografia de parte do pavimento (U.E. [262]) e da estrutura de adobe (U.E. [260]) da Fase 4. 


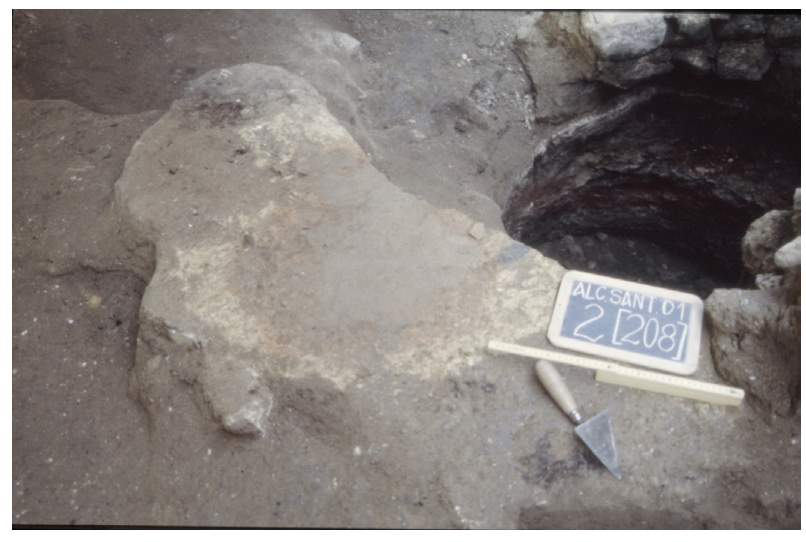

Fig. 11 - Fotografia da estrutura de combustão (U.E. [208]).

\subsection{O conjunto artefactual}

Os níveis integrados nesta quarta fase de ocupação da Idade do Ferro proporcionaram 136 fragmentos classificáveis (108 NMI). Distribuem-se pelas seguintes categorias: cerâmica manual $(27,78 \%)$, ânforas $(0,93 \%)$, cerâmica cinzenta $(47,21 \%)$, cerâmica de engobe vermelho $(10,19 \%)$, cerâmica comum $(5,56 \%)$, cerâmica pintada $(6,48 \%)$ e outros $(1,85 \%)$.

Pela primeira vez na estratigrafia observada em 2001, a cerâmica manual corresponde à segunda categoria mais representada, sendo superada pelas produções cinzentas. Nesta fase, as produções manuais englobam apenas 37 fragmentos (30 NMI), dois dos quais inclassificáveis (2 NMI). As formas abertas permanecem as mais abundantes, integrando taças carenadas (8 NMI - Fig. 21, no 315 a 319) e tigelas (9 NMI - Fig. 21, no 320 a 326). Entre estas últimas, deve destacar-se a presença de um exemplar com decoração brunida na superfície interna (Fig. 21, n. ${ }^{\mathrm{o}}$ 324) e um outro com vestígios da decoração sobre-pintada, branca e vermelha (Fig. 21, n. ${ }^{\circ}$ 323). Nas formas abertas, constam ainda dois fragmentos de diâmetro amplo, que poderão corresponder a pratos (2 NMI - Fig. 21, n. 327 e 328). Um outro exemplar apresenta um diâmetro superior (1 NMI - Fig. 21, n.o 329), podendo eventualmente ter feito parte de uma tampa, ainda que não se possa excluir a possibilidade de pertencer a uma tigela de maiores dimensões.

As formas fechadas estão representadas exclusivamente por potes de perfil em S (8 NMI - Fig. 21, n. ${ }^{\circ} 330$ a 333, 336), dois dos quais com decoração incisa sobre o bordo (Fig. 21, n.. 333).
Deste conjunto fazem ainda parte duas bases planas, um fundo em ônfalo (Fig. 21, n. ${ }^{\circ} 337$ ), um fragmento decorado com ungulações (Fig. 21, n. ${ }^{\mathrm{o}}$ 334), uma parede com vestígios de decoração sobre-pintada vermelha e branca e duas carenas (Fig. 21, n. ${ }^{\circ} 319$ ).

Tal como ocorre nas fases anteriores, as ânforas são raras, contabilizando-se apenas um fragmento classificável (1 NMI - Fig. 20, n. ${ }^{\circ}$ 266), que se integra no tipo 10.1.2.1 de Ramon Torres. Tal como os exemplares anteriores, as características da sua pasta permitem propor uma origem na costa de Málaga.

A cerâmica de engobe vermelho conta com 15 fragmentos (11 NMI), um dos quais inclassificável (1 NMI). Os pratos permanecem como o tipo formal mais bem representado (8 NMI - Fig. 20, no 267 a 272), tendo perfis bem conservados que permitem uma apreciação formal mais específica. Um deles (Fig. 20, n. ${ }^{\circ}$ 269), com $22 \mathrm{~cm}$ de diâmetro e $2 \mathrm{~cm}$ de largura de bordo, é ainda integrável no tipo P1 de Rufete Tomico (1988-1989). Os restantes quatro são já enquadráveis no P2 (Fig. 20, n. ${ }^{\circ} 272-20 \mathrm{~cm}$ de diâmetro e $3,8 \mathrm{~cm}$ de largura de bordo; Fig. 20, n. ${ }^{0} 271-22 \mathrm{~cm}$ de diâmetro e $3,9 \mathrm{~cm}$ de largura de bordo; Fig. 20, n. . $268-24,1 \mathrm{~cm}$ de diâmetro e 4,8 cm de largura de bordo; Fig. 20, n. ${ }^{\circ} 267-25,2 \mathrm{~cm}$ de diâmetro e 3,7 cm de largura de bordo). Menos representadas encontram-se as taças (1 NMI Fig. 20, n. $\left.{ }^{\circ} 273\right)$, de corpo hemisférico e bordo pendente. É difícil encontrar um paralelo exacto para esta forma, que, contudo, apresenta certas semelhanças com a forma III.B.3.a proposta por V. Freitas para o Castelo Castro Marim, ainda que esta exiba um perfil mais carenado. Esta forma está presente nas Fases IV e $\mathrm{V}$ do sítio algarvio, para as quais se atribui uma cronologia centrada no século VI e V-III a.C., respectivamente (Freitas 2005). Um outro exemplar (1 NMI - Fig. 20, n. ${ }^{\circ}$ 274) apresenta dimensões muito reduzidas, o que dificulta a sua equiparação a uma forma específica podendo, contudo, corresponder a uma forma fechada. No conjunto de cerâmica de engobe vermelho da Fase 4 contam-se ainda três fragmentos de fundo aplanados, com pé ligeiramente indicado (Fig. 20, n. ${ }^{\circ}$ 275 e 276), provavelmente pertencentes aos pratos anteriormente descritos, e ainda um fragmento de carena.

A cerâmica com decoração pintada está representada por 12 fragmentos (7 NMI). A maioria dos materiais que permitiram uma classificação tipoló- 
gica pertencem a pithoi (6 NMI - Fig. 20, n. ${ }^{\circ} 278$ a 281), com colos rectilíneos e bordos esvertidos, cuja secção pode ser circular ou apontada. Um único exemplar (1 NMI - Fig. 20, n. ${ }^{\circ}$ 277) apresenta um colo mais curto e curvilíneo, sendo integrável no tipo 10Bb da Rua dos Correeiros (Sousa 2014). Neste conjunto, contam-se ainda quatro fragmentos de paredes com bandas pintadas em tons de vermelho e cinzento (Fig. 20, n. ${ }^{\circ}$ 282) e um fragmento de asa.

A cerâmica cinzenta integra 56 fragmentos (51 $\mathrm{NMI}$ ), três dos quais inclassificáveis (3 NMI), constituindo a categoria mais bem representada. Tal como ocorre nas restantes fases, a tigela é a forma dominante (35 NMI - Fig. 20, $\mathrm{n}^{\mathrm{O}} 283$ a 294, 298), sendo mais frequentes as de bordo engrossado quando comparadas com as de perfil simples. Entre estas últimas, deve, contudo, destacar-se um exemplar (Fig. 20, n. . 298), de tamanho francamente reduzido. Outros fragmentos $(5 \mathrm{NMI})$, de menores dimensões, parecem corresponder a pequenas taças de paredes pouco oblíquas (Fig. 20, n. ${ }^{\circ} 299$ a 302), uma das quais com bordo assinalado (Fig. 20, n. ${ }^{\circ}$ 300 ). Entre as formas abertas, identificaram-se ainda dois fragmentos de taças carenadas (2 NMI Fig. 21, n. ${ }^{\circ} 303$ e 306 ), uma delas com dimensões ligeiramente superiores às das restantes (Fig. 21, n. ${ }^{0}$ 306). Outros seis fragmentos (6 NMI - Fig. 20 e 21, n. $\left.{ }^{\circ} 295,296,297,304,305\right)$ são mais difíceis de classificar, podendo, contudo, corresponder a bordos de potes, possivelmente de perfil em $\mathrm{S}$, que surgem pela primeira vez na estratigrafia da Alcáçova de Santarém. O conjunto de cerâmica cinzenta conta ainda com uma carena, três fragmentos de fundo aplanado (Fig. 21, n. .307 ), e ainda um pé robusto, que poderá eventualmente corresponder à base de um vaso tipo trípode (Fig. 21, n. ${ }^{\mathrm{o}}$ 308).

A cerâmica comum a torno está representada por 13 fragmentos (6 NMI). A forma dominante é o pote/panela de perfil em S (5 NMI - Fig. 21, n. ${ }^{\circ}$ 309, 310, 312, 313), que exibe, com frequência, marcas de exposição ao fogo, sendo a única outra forma identificada uma tigela hemisférica de bordo simples (1 NMI). Nesta categoria cabem ainda cinco fragmentos de fundo, de perfil aplanado, com (Fig. 21, n. ${ }^{\circ} 311$ ) ou sem pé destacado (Fig. 21, n.․․ 314), um outro de perfil marcadamente convexo e um fragmento de asa de secção circular.

Ao conjunto da Fase 4 pertencem também duas peças de cerâmicas perfuradas $(2 \mathrm{NMI})$, que poderão corresponder a fragmentos de copelas (Fig. 21, n. $\left.{ }^{\circ} 335\right)$.

\subsection{Discussão e apreciação cronológica}

As características dos materiais recolhidos na Fase 4 evidenciam uma clara transformação no quadro da cultura material da Alcáçova de Santarém, observando-se, pela primeira vez, um predomínio das cerâmicas cinzentas sobre as produções manuais. Apesar do repertório formal das primeiras permanecer pouco diversificado, sendo dominado por recipientes de tipo tigela, regista-se a introdução, neste momento, de uma nova forma que parece integrar pequenos potes de paredes finas e de perfil em S. É também importante destacar o aparecimento de um fragmento de fundo que consideramos possível ter pertencido a um vaso trípode.

No conjunto das produções manuais, que continuam a ser numericamente expressivas, mantém-se o elenco morfológico das fases anteriores, sendo apenas de destacar a presença de um fragmento com decoração brunida no interior que evidencia a permanência, durante a Idade do Ferro, desta técnica decorativa típica do Bronze Final.

A maioria dos materiais de matriz orientalizante exibem características similares aos das fases anteriores (ânforas tipo 10.1.2.1 e pratos de engobe vermelho dos tipos P1 e P2 de Rufete Tomico). Contudo, deve realçar-se a presença de uma taça de corpo semi-hemisférico e bordo pendente cujos paralelos mais próximos se encontram nos contextos do século VI a.C. do Castelo de Castro Marim (Freitas 2005). Para uma cronologia mais tardia remetem também as características dos bordos de dois dos pithoi identificados, que apresentam um bordo apontado, assim como um outro vaso semelhante ao tipo $10 \mathrm{Bb}$ da Rua dos Correeiros. Assim, e considerando todos estes elementos, é possível que esta quarta fase se integre cronologicamente no século VI a.n.e., porventura nos seus inícios ou na sua primeira metade.

A permanência de vasos com paredes perfuradas que se podem relacionar com as actividades metalúrgicas não pode também ser esquecida.

\section{FASE 5}

\subsection{Os elementos estratigráficos}

Tal como ocorreu na Fase 3, este momento de ocupação parece integrar uma etapa intermédia formada por uma série de estratos de derrube e, sobretudo, de aterro (U.E.s [228], [227], [229], [245], [246], [247], [240], [232], [239], [244], [237], [276]), utilizados, em algumas ocasiões, como solos de ocupação, estando um deles associado a uma pequena fos- 
sa (U.E. [231] - enchimento [226]), e que serviram de plataforma para as construções da Fase 6.

\subsection{O conjunto artefactual}

Esta fase intermédia da sequência de ocupação sidérica da Alcáçova de Santarém proporcionou 150 fragmentos classificáveis (119 NMI). Distribuem-se pelas seguintes categorias: cerâmica manual $(34,45 \%)$, ânforas $(2,52 \%)$, cerâmica cinzenta $(44,55 \%)$, cerâmica de engobe vermelho $(5,88 \%)$, cerâmica comum $(4,20 \%)$, cerâmica pintada $(3,36 \%)$ e outros $(5,04 \%)$.

A cerâmica de produção manual conta com 50 fragmentos (41 NMI), cinco dos quais inclassificáveis ( $5 \mathrm{NMI})$. Tal como no momento anterior, as formas abertas estão representadas pelas tigelas (8 NMI - Fig. 23, no 385 a 390, 399), três das quais com vestígios de decoração sobre-pintada vermelha e branca (Fig. 23, n. ${ }^{\circ} 385$ a 387), e pelas taças de perfil carenado (11 NMI - Fig. 23, no 391 a 398), apresentando também um destes vasos restos de engobe de idênticas tonalidades (Fig. 23, n. ${ }^{\circ} 395$ ).
Nestas últimas, verifica-se, contudo, uma diferença substancial em termos morfológicos, porque, embora tenham permanecido as morfologias típicas das fases anteriores (Fig. 23, n.. 395), o bordo deixa de estar indicado, apresentando-se na continuidade do corpo (Fig. 23, n. 391 a 393). Nas formas abertas, integra-se ainda um outro recipiente, de grande dimensão, podendo corresponder a algum tipo de bacia e/ou alguidar (1 NMI - Fig. 23, n. ${ }^{\circ} 384$ ), com paredes rectilíneas e bordo simples, ligeiramente esvertido.

No grupo das formas fechadas, foram identificadas várias morfologias, na sua maioria já reconhecidas nas fases anteriores, como é o caso dos potes de bordo vertical (2 NMI - Fig. 23, n. ${ }^{\circ} 411$ ), um dos quais decorado com digitações sobre cordão plástico aplicado, potes de perfil em S (7 NMI - Fig. 23, no 402 a 405), que podem apresentar o bordo engrossado (Fig. 23, n. ${ }^{\mathrm{O}} 404,405$ ) e decoração incisa na parte superior (Fig. 23, n. ${ }^{\circ} 402,403$ ), e três exemplares com colo alto e desenvolvido, que pensamos poderem corresponder a jarros (3 NMI

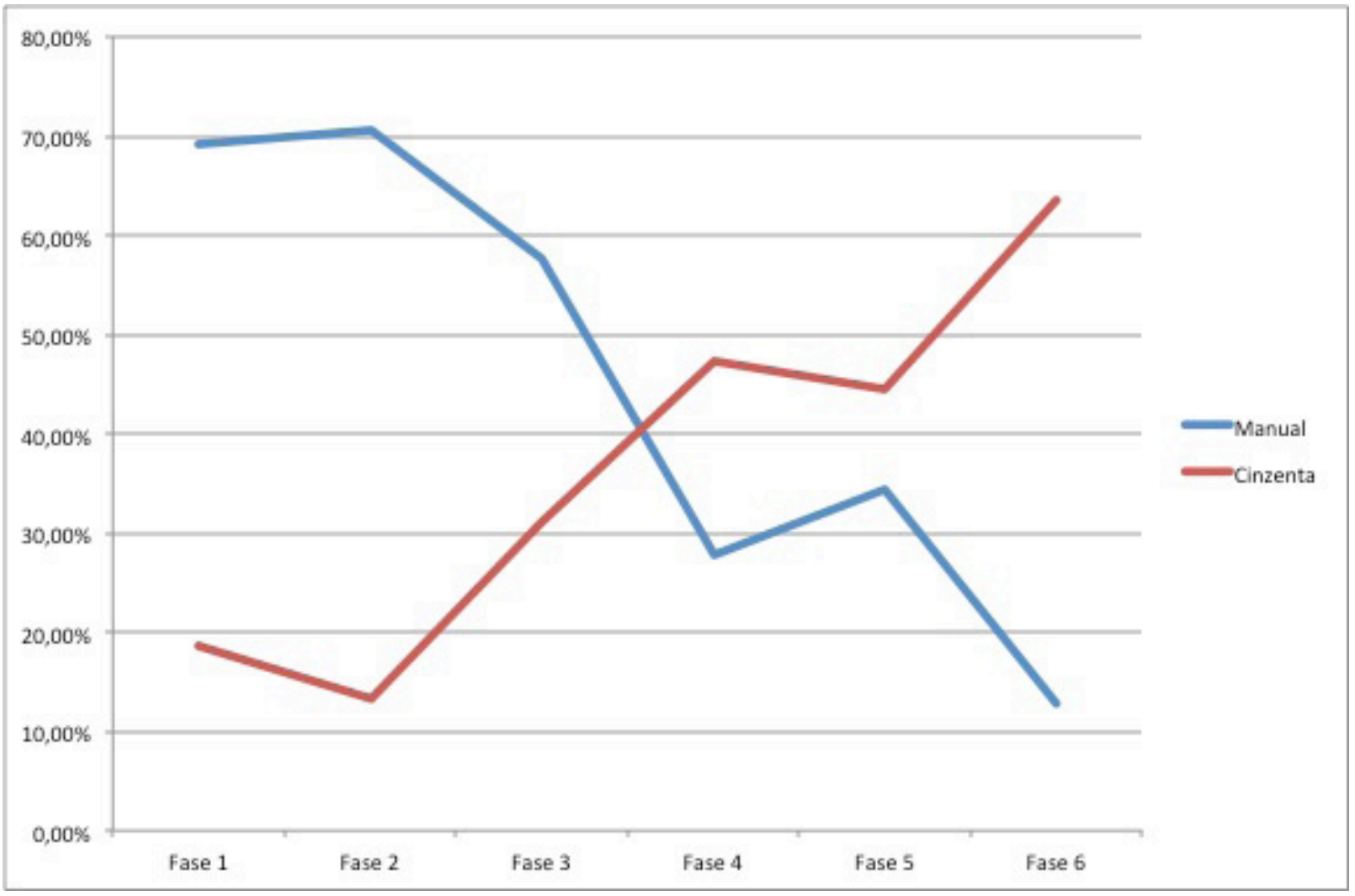

Fig. 12 - Gráfico da distribuição das produções manuais e da cerâmica cinzenta de acordo com as fases estabelecidas (base \% NMI). 
- Fig. 23, n. ${ }^{\circ}$ 406, 410, 415), um dos quais possui uma pequena moldura no bordo (Fig. 23, n.. 415). Por último, identificou-se um fragmento de bordo esvertido e colo oblíquo bem desenvolvido, que poderá corresponder a um vaso "à chardon" (1 NMI - Fig. 23, n.. 407).

Pela primeira vez, surgem, nesta categoria, pequenos recipientes fechados, de corpo globular e bordo vertical (3 NMI - Fig. 23, n. $\left.{ }^{\circ} 400,401\right)$, que recordam as produções de cerâmica cinzenta, presentes na própria Alcáçova de Santarém (Forma 4 - Arruda 1999-2000: 200-201) e em Lisboa (Tipo 3 - Arruda, Freitas e Vallejo Sánchez 2000: 32). Tal como estas últimas, poderá tratar-se de recipientes destinados ao consumo de líquidos.

No conjunto, inclui-se ainda um fragmento de carena, duas paredes com vestígios de decoração sobre-pintada vermelha e branca, uma outra decorada com sulcos brunidos na superfície externa (Fig. 23, n. ${ }^{\circ} 409$ ) e cinco fundos aplanados (Fig. 23, n. ${ }^{\circ} 416$ ), por vezes com pé destacado (Fig. 23, n. ${ }^{\circ} 408$ ).

As ânforas encontram-se representadas por três fragmentos (3 NMI - Fig. 22, n. ${ }^{\circ} 338$ a 340), todos eles pertencentes ao tipo 10.1.2.1 de Ramon Torres, sendo de realçar que um exemplar se encontra coberto por pintura vermelha em ambas as superfícies. As características das pastas sugerem, uma vez mais, uma origem na costa de Málaga.

A cerâmica de engobe vermelho está representada por nove fragmentos (7 NMI). Os pratos são a forma mais recorrente (5 NMI - Fig. 22, n. 341 e 342 ), tendo o exemplar mais bem conservado (Fig. 22, n. ${ }^{\circ} 341$ ) um diâmetro de 21,2 cm e uma largura de bordo de $3 \mathrm{~cm}$, equiparando-se ao tipo P1 de Rufete Tomico (1988-1989). No conjunto integra-se ainda um pequeno fragmento de bordo (1 NMI - Fig. 22, n. $\left.{ }^{\circ} 343\right)$, que poderá corresponder a uma taça semelhante à registada na Fase 4, e uma parede de uma forma fechada (1 NMI - Fig. 22, n. ${ }^{\circ} 344$ ), possivelmente pertencente a algum tipo de unguentário. Por último, deve referir-se a existência de um fragmento de fundo aplanado(Fig. 22, n.. 345) e de uma carena, ambos pertencentes, provavelmente, a pratos.

A cerâmica pintada conta com dez fragmentos (4 NMI), pertencentes a pithoi de bordo esvertido e colos tronco-cónicos, mas de paredes ligeiramente convexas (Fig. 22, n. .346 a 348), de bordo pendente e colo oblíquo, sendo os restantes fragmentos paredes (Fig. 22, n. . 349 a 353). A pintura das paredes do corpo é em bandas vermelhas, ou, mais raramente, em traços que desenham um recticulado.
A cerâmica cinzenta conta com 62 fragmentos (53 NMI), um dos quais inclassificável (1 NMI). A forma mais abundante continua a ser a tigela, de perfil hemisférico (42 NMI), com bordo geralmente engrossado (Fig. 22, n. ${ }^{\circ} 366$ a 369), de perfil simples (Fig. 22, n. ${ }^{\circ} 355,356,364,365,371$ ), ou então assinalado externamente (Fig. 22, n. $^{\circ} 358$ a 361). Identificaram-se também alguns exemplares semelhantes, mas com paredes mais rectilíneas $(2$ NMI - Fig. 22, n.o 370 e 372). Nas formas abertas, integram-se dois fragmentos de taças carenadas (2 NMI), de bordo simples (Fig. 22, n. . 363 ) ou esvertido (Fig. 22, n. ${ }^{\circ} 362$ ), uma outra de paredes oblíquas e bordo assinalado (1 NMI - Fig. 22, n. ${ }^{\mathrm{o}}$ $357)$ e três fragmentos de pratos (3 NMI) de bordo aplanado, com lábio assinalado no interior (Fig. 22, n..$^{\circ} 373$ ) ou no exterior (Fig. 22, n. $\left.{ }^{\circ} 374,375\right)$. Nesta fase registou-se apenas um exemplar pertencente a uma forma fechada de características particulares. Trata-se de um bordo de um pithos (1 NMI - Fig. 22 , n. ${ }^{\circ} 354$ ), com bordo esvertido e colo sub-tronco-cónico, de paredes convexas, coberto, na área superior, por um engobe vermelho acastanhado. Curiosamente, e ao contrário de todas as outras peças de cerâmica cinzenta, que são cuidadosamente polidas, este exemplar apresenta as superfícies grosseiras. Neste conjunto, integra-se ainda uma asa, de secção bífida, que provavelmente corresponde ao pithos anteriormente referido, sete fragmentos de fundo aplanado, geralmente com pé destacado (Fig. 23 , n. ${ }^{\text {o }} 376$ e 378 ), e um outro côncavo, que pode, eventualmente, corresponder a uma forma inspirada nas oil bottles (1 NMI - Fig. 23, n. ${ }^{\circ} 377$ ).

A cerâmica comum a torno está representada por nove fragmentos (5 NMI), dois dos quais inclassificáveis (2 NMI). Integra tigelas hemisféricas de bordo engrossado (1 NMI - Fig. 23, n. . 379), um grande recipiente de bordo esvertido e secção arredondada (1 NMI - Fig. 23, n.. 380) e outros dois fragmentos (1 NMI) que correspondem, provavelmente, a um mesmo recipiente, de tipo pote / panela (Fig. 23, n. ${ }^{\circ} 381$ e 382). A este conjunto pertencem também duas bases planas, uma das quais com pé destacado (Fig. 23, n.o 383), e um fragmento de asa de secção oval.

No conjunto da Fase 5, contam-se ainda quatro artefactos de cerâmica (6 NMI) que se podem relacionar com actividades metalúrgicas. Destes, três correspondem provavelmente a copelas, com paredes perfuradas (Fig. 23, n. ${ }^{\circ} 413$ e 414). Uma outra peça (Fig. 23, n.. 417), também perfurada, 
parece tratar-se de um tubo de ventilação ou da parte cerâmica de um fole, sendo semelhante a um outro artefacto recuperado em área próxima, neste caso associado a estruturas interpretadas como eventuais fornos destinados à metalurgia (Arruda 1999-2000: 216). Outros dois artefactos de cerâmica são mais difíceis de definir quanto à função, e, assim, de interpretar. O primeiro (Fig. 23, n. $^{\circ} 418$ ) corresponde a um cilindro, perfurado verticalmente, que possui uma acentuada convexidade numa das faces, sendo a outra convexa. Não pudemos encontrar qualquer paralelo para este artefacto, sendo também impossível indicar uma função concreta para ele. A restante (Fig. 23, no 419) trata-se de uma esfera achatada, de secção elíptica, maciça, que podíamos paralelizar com as chamadas "bolas de argila" do mundo celtibérico, vetão e vaceu, mas também estremenho e andaluz (Almagro Gorbea 2008: 749-750). Contudo, nestes casos, as peças são esféricas e possuem dimensão mais reduzida. A indefinição da sua funcionalidade é também evidente no território actualmente espanhol, onde já foram interpretados como objectos lúdicos (berlindes ou peças de outros jogos), projecteis de funda, elemento pre-monetário, mas também apotropaicos e mesmo como elementos de identificação étnica (ibidem). No caso ribatejano, que se diferencia pelas dimensões e pelo perfil elíptico, não há dados que ajudem ao esclarecimento da questão funcional. Podemos, todavia, avançar que ambos os artefactos foram recuperados na mesma unidade, que, aliás, forneceu igualmente, um fragmento de um algaraviz.

\subsection{Discussão e apreciação cronológica}

No conjunto associável a esta quinta fase da ocupação da Idade do Ferro da Alcáçova de Santarém mantém-se a tendência observada no momento precedente no âmbito do domínio das produções cinzentas na cultura material. Existem, contudo, algumas diferenças pontuais que devem ser assinaladas. No quadro das produções manuais, assiste-se a uma evolução numa das morfologias abertas mais recorrentes, a taça carenada, registando-se em alguns exemplares a simplificação do perfil, que adquire características mais rectilíneas, e que se diferencia, pela primeira vez, com alguma facilidade, do elenco tipológico que remonta ao Bronze Final. Por outro lado, deve assinalar-se a introdução de recipientes abertos, tipo bacia e/ou alguidar, e ainda de uma outra morfologia, aparentemente inspirada em protótipos das produções cinzentas, que corresponde a pequenos vasos de bordo vertical, e que poderão remeter para um horizonte cronológico mais tardio dentro do século VI a.C., centrado possivelmente nos seus meados ou segunda metade.

No âmbito do elenco morfológico da cerâmica cinzenta, cabe destacar a identificação de um $p i$ thos, que aparece pela primeira vez nesta produção, e do fragmento de um fundo que poderá corresponder à base de uma oil bottle. Os restantes materiais de cariz orientalizante são indiferenciáveis dos recolhidos em momentos anteriores, pelo que não acrescentam dados relevantes para a esta discussão, para além da óbvia continuidade dos respectivos elencos morfológicos.

Por último, cabe destacar a quantidade expressiva de objectos possivelmente relacionados com as actividades metalúrgicas (copelas, algaravizes) ainda que, infelizmente, não possam ser associados a um contexto específico.

\section{FASE 6}

\subsection{Estratigrafia}

A fase mais recente da ocupação da Idade do Ferro detectada na campanha de 2001 encontrava-se profundamente afectada pelas construções mais recentes. Com efeito, a maioria das camadas identificadas tinha uma extensão reduzida, sendo difícil compreender a sua relação estratigráfica. A este momento foram associados os restos de duas estruturas de combustão, U.E.s [197] e [208] (Fig. 11), formadas por fragmentos cerâmicos justapostos. Sob esta última, identificou-se ainda uma outra estrutura similar (U.E. [211]), de contornos ovalados, encaixada numa pequena depressão preenchida por cinzas e carvões (U.E.s [209] e [210]), e uma outra vala (U.E. [183] - enchimento [178]). Estas pequenas fossas foram escavadas no topo de dois estratos de aterro (U.E.s [212] e [213=184]), cuja área superior terá sido usada como solo de ocupação.

A esta fase foi possível ainda associar uma estrutura (U.E. [225]), de orientação N-S, construída com blocos de calcário, que apoiava um nível de ocupação (U.E. [207]), realidade que se poderá também relacionar com os estratos [181], [185=215], [206], [219], [222], [233], [236] e [275], ainda que, devido à profunda afectação registada na área, não tenha sido possível observar uma relação directa. 


\subsection{O conjunto artefactual}

A última fase da Idade do Ferro detectada na escavação de 2001 é a mais bem representada em termos quantitativos, englobando 247 fragmentos (203 NMI). Deve, contudo, referir-se que sete destas peças ( $7 \mathrm{NMI}-3,45 \%$ do conjunto) correspondem a intrusões, possivelmente resultantes de contaminações de camadas superiores. As restantes distribuem-se pelas seguintes categorias: cerâmica manual $(12,81 \%)$, cinzenta $(63,54 \%)$, engobe vermelho $(6,40 \%)$, comum $(9,36 \%)$, pintada $(2,96 \%)$ e outros artefactos $(1,48 \%)$.

As produções manuais contam com 31 fragmentos (26 NMI), nove dos quais (9 NMI) inclassificáveis. As formas abertas são, uma vez mais, dominadas pelas tigelas de perfil simples (8 NMI - Fig. $26, \mathrm{n}^{\mathrm{0}} 509$ a 514 ), três das quais com vestígios de pintura vermelha e branca (Fig. 26, n. ${ }^{\circ}$ 510, 512, 513). Um outro exemplar semelhante, mas de maiores dimensões e com bordo bem assinalado na área externa (1 NMI - Fig. 26, n.. 515), e uma taça carenada (1 NMI), enquadram-se também neste grupo.

As formas fechadas englobam potes de perfil em S (5 NMI - Fig. 26, n.. 517 a 519), um dos quais com ungulações sobre o bordo (Fig. 26, n. ${ }^{\circ}$ 519), potes de bordo vertical (1 NMI), e um bordo possivelmente correspondente a um vaso à chardon (1 NMI - Fig. 26, n. ${ }^{\circ}$ 516).

Neste conjunto, documentaram-se ainda dois fundos a planados e três em ônfalo (Fig. 26, n. 520 , $522,523)$, um dos quais com marca incisa dentro de um círculo na área interna (Fig. 26, n. ${ }^{\circ} 522$ ).

A cerâmica de engobe vermelho está bem representada no conjunto, com 19 fragmentos (13 NMI). A forma mais expressiva continua a ser o prato $(12$ NMI), de bordo já bastante aplanado (Fig. 24, n. ${ }^{\circ} 420$ a 424), perdendo-se o lábio interno ou então situando-se este numa área bem mais inferior, sendo estas características típicas das fases mais tardias destas produções, verificáveis, por exemplo, no tipo P3 de Rufete Tomico (1988-1989), estabelecido para a área de Huelva. A única outra forma representada corresponde a um pequeno fragmento, com bordo assinalado na área externa e paredes oblíquas, que poderá pertencer a algum tipo de pequeno vaso ou unguentário (1 NMI - Fig. 24, n. . 425). A este conjunto pertencem dois fragmentos de carena e quatro fundos de perfil convexo(Fig. 24, n. ${ }^{\circ} 426$ ), que provavelmente correspondem aos pratos anteriormente descritos.

A cerâmica com decoração pintada está representada por 15 fragmentos (6 NMI). A maioria cor- responde a pithos (5 NMI), com colos oblíquos (Fig. 24, n. ${ }^{\circ} 428$ ) ou curvilíneos (Fig. 24, n. ${ }^{\circ} 427$ ). Um outro recipiente, com colo suave e bordo esvertido, parece integrar-se no grupo dos potes (1 NMI - Fig. 24, n. $\left.{ }^{\circ} 429\right)$. Neste grupo contabilizaram-se ainda três fragmentos de asa de secção bífida (Fig. 24, n. ${ }^{\circ} 430$ ) e seis paredes pintadas com bandas em tons de vermelho e negro (Fig. 24, n. ${ }^{\circ}$ 431 a 434), uma das quais formando um motivo reticulado (Fig. 24, n. ${ }^{\circ} 431$ ).

A cerâmica cinzenta é a categoria mais bem representada, com 142 fragmentos (129 NMI), 18 dos quais inclassificáveis (18 NM). A forma mais recorrente é a tigela (68 NMI - Fig. 24, no 435 a 454), geralmente de tendência hemisférica, com bordo simples, engrossado ou mesmo assinalado no exterior (Fig. 24, n. ${ }^{\circ} 438,445$ a 447, 449, 454) e, mais raramente, de paredes rectilíneas (Fig. 24, n. ${ }^{\circ} 450$ a 452). As taças são mais raras, englobando perfis carenados (3 NMI - Fig. 25, n. ${ }^{\circ} 473,474$ e 476), corpos semi-hemisféricos e bordos esvertidos (4 NMI - Fig. 25, n. 470 a 472), uma das quais com decoração incisa no exterior (Fig. 25, n. $\left.{ }^{\circ} 471\right)$, e, sobretudo, recipientes com paredes oblíquas (21 NMI), de bordo simples (Fig. 25, n..$^{\circ}$ $460,462,466$ ) ou assinalado (Fig. 24 e 25, n. ${ }^{\circ} 455$ a $459,461,463$ a 465,467 a 469,475$)$. No conjunto das formas abertas contam-se ainda vários fragmentos de pratos (9 NMI - Fig. 25, n. ${ }^{\circ} 477$ a 481), de lábio curto, com excepção de um único exemplar (Fig. 25, n. ${ }^{\circ} 480$ ), cujo bordo é mais aplanado. Entre as formas fechadas, identificou-se um fragmento de bordo esvertido e ligeiramente engrossado (1 NMI - Fig. 25, n. ${ }^{\circ} 484$ ), possivelmente de um recipiente de tipo pote, assim como outras três formas semelhantes (3 NMI - Fig. 25, n. $\left.{ }^{\circ} 485\right)$, mas de perfil mais suave, que encontram o seu paralelo mais próximo no tipo $4 \mathrm{Aa}$ da Rua dos Correeiros (Sousa 2014). Duas outras peças de bordo simples, de tendência vertical e colo curto, que poderão corresponder a pequenos potes ou mesmo a algum tipo de jarro (2 NMI - Fig. 25, n. $\left.{ }^{\circ} 482,483\right)$. Registaram-se ainda duas carenas e doze fragmentos de fundo, dos quais dois são aplanados, com (Fig. 25, n. $\left.{ }^{\circ} 490,491\right)$ e sem (Fig. 25 , n. $\left.{ }^{\circ} 488,489,493\right)$ pé destacado, e, mais raramente, de perfil convexo (Fig. 25, n. ${ }^{\circ} 492$ ) ou em ônfalo (Fig. 25, n. ${ }^{\circ} 486,487$ ), um dos quais com um grafito na zona interna, composto por um $\mathrm{X}$ circundado por um círculo (Fig. 25, n. ${ }^{\circ} 487$ ). 
A cerâmica comum a torno conta com 30 fragmentos (19 NMI), cinco dos quais inclassificáveis (5 NMI). As formas abertas são escassas, englobando exclusivamente algumas tigelas semi-hemisféricas de bordo engrossado (2 NMI). A forma mais representada é o recipiente de perfil em $\mathrm{S}$, de tipo pote/ panela (10 NMI - Fig. 26, n. ${ }^{\circ} 495,497$ a 501), cuja morfologia se assemelha ao que foi definido como tipo 10Aa na Rua dos Correeiros, em Lisboa (Sousa 2014). Estes vasos de Santarém apresentam, com frequência, marcas de exposição ao fogo, o que indicia a utilização destas peças na confecção de alimentos. Um outro exemplar (1 NMI - Fig. 26, n. ${ }^{\circ}$ 496), de perfil mais suave, recorda o tipo 10Ca do sítio lisboeta, e um outro ainda (1 NMI - Fig. 26, n. ${ }^{\circ}$ 494), de bordo esvertido, o tipo 10Ba (Sousa 2014). Neste conjunto, integra-se ainda um fragmento de parede com decoração incisa na superfície interna (Fig. 26, n. ${ }^{\circ}$ 502), sem que seja possível distinguir correctamente o motivo representado, uma asa de secção circular e nove fragmentos de fundo, geralmente aplanados (Fig. 26, n. ${ }^{\circ} 503,507,508$ ) e, por vezes, com pé destacado (Fig. 26, n. ${ }^{\circ} 504$ a 506), e, em um único caso, convexo. Deve ainda referir-se que um destes exemplares (Fig. 26, n. ${ }^{0}$ 507) apresenta uma decoração incisa no interior, com linhas oblíquas e onduladas.

Entre o conjunto desta última fase registaram-se ainda dois fragmentos cerâmicos (2 NMI - Fig. 26 , n. 521 e 524 ) que poderão pertencer a copelas, e uma peça de osso polido, possivelmente um cabo de instrumento (1 NMI - Fig. 26, n.. 525).

\subsection{Discussão e apreciação cronológica}

A última fase da ocupação sidérica registada na campanha de 2001 mantém, em linhas gerais, as mesmas características verificadas na anterior. Destaca-se apenas a introdução, no quadro das produções de engobe vermelho, de pratos de bordo mais aplanado, que se aproximam já dos tipos mais tardios. Trata-se de um conjunto que apresenta várias semelhanças com um outro exumado em Lisboa, na área da Sé (Arruda 1999-2000), podendo integrar-se já em momentos avançados do século VI a.C., eventualmente na sua segunda metade. Entre as produções de engobe vermelho, cabe ainda realçar a presença de um pequeno vaso de tipo unguentário, que remete para utilizações sobretudo de cariz sumptuário e que se junta a outros fragmentos similares recolhidos nas fases mais antigas.
No elenco tipológico da cerâmica cinzenta cabe destacar a presença, nesta última fase, de pequenas formas fechadas que encontram o seu melhor paralelo na zona de Lisboa (tipo 4Aa da Rua dos Correeiros - Sousa 2014) e que remetem também para momentos tardios dentro da I Idade do Ferro. $\mathrm{O}$ mesmo se poderia aplicar às similitudes que se verificam no quadro de alguns recipientes fechados de cerâmica comum, que se aproximam já de tipos evoluídos que se irão tornar sobretudo abundantes a partir dos meados do $1^{\mathrm{O}}$ milénio (Sousa 2014).

Por último deve ainda referir-se a presença de elementos que se podem relacionar com o desenvolvimento de práticas metalúrgicas, que são uma constante ao longo de toda a diacronia sidérica detectada na campanha de 2001 da Alcáçova de Santarém.

9. NOVAS CONTRIBUIÇÕES PARA A LEITURA DA OCUpação da I Idade do Ferro na Alcáçova de SantaRÉM

Os dados obtidos na campanha realizada em 2001 na Alcáçova de Santarém permitiram ler, pela primeira vez de forma clara, a evolução da cultura material deste sítio emblemático ao longo da primeira metade do $1^{\circ}$ milénio a.n.e. O espaço intervencionado proporcionou evidências que sugerem uma intensa ocupação humana datável da Idade do Ferro que se sobrepôs aos níveis do Bronze Final, manifestada por uma densa sobreposição de ambientes onde se sucedem diversas fases de construção, abandono e remodelação das áreas habitadas.

Os primeiros vestígios artefactuais que se podem relacionar inequivocamente com a presença de agentes fenícios nesta área são datáveis, em cronologia tradicional, num momento centrado entre finais do século VIII a.n.e. e inícios da centúria seguinte (Fase 1), e poderão integrar-se no intervalo de tempo proporcionado pelas datações radiométricas obtidas em outras áreas intervencionadas em campanhas anteriores (finais do século IX - inícios do século VIII cal BC - Arruda 1999-2000: 217; 2005a). Durante esta primeira fase, os artefactos de cariz orientalizante não são muito significativos quantitativamente, mas reúnem já as categorias e morfologias cerâmicas típicas destes momentos (pratos de engobe vermelho, pithos e urnas tipo Cruz del Negro com decoração pintada em bandas, tigelas, taças e pratos de cerâmica cinzenta e potes de cerâmica comum). Neste conjunto deve destacar-se, pela sua excepcionalidade, a presença 
de um fragmento que poderá corresponder à base de uma oil bottle, possivelmente importada da área meridional do território peninsular. A presença deste exemplar poderá evidenciar a aquisição de produtos de cariz sumptuário, neste caso concreto de substâncias aromáticas, pelas comunidades da Alcáçova de Santarém já durante os momentos iniciais da Idade do Ferro, acrescentando-se, em fases sucessivas, outros elementos de idêntica ou similar conotação.

É, contudo, importante sublinhar, neste primeiro momento, o forte domínio das produções manuais, que se inserem numa clara linha de continuidade com a fase do Bronze Final (Arruda e Sousa 2015), e que se reflecte na contínua reprodução dos mesmos protótipos formais, diferindo apenas no quadro decorativo, com o desaparecimento de motivos e técnicas de inspiração mesetenha (de tipo Cogotas) mas, simultaneamente, com a introdução da aplicação de pinturas de tonalidades vermelhas e brancas, que recordam as de estilo Medellín, que podem remeter, uma vez mais, para influências dessas áreas mais interiores. Os motivos incisos e mesmo os brunidos, apesar de mais escassos, não desapareceram do repertório decorativo (Arruda 1999-2000: 183-184), estando presentes até, pelo menos, ao final do século VI a.n.e.

Um último comentário deve ser assinalado relativamente ao facto de o elenco morfológico desta categoria, identificado já em outras áreas da Alcáçova (Arruda 1999-2000: 175-176), cobrir praticamente todas as necessidades da vida quotidiana (serviço de mesa, cozinha, armazenamento), e que nenhuma das formas parece ter sido integralmente substituída pelos vasos "orientalizantes", com os quais são usadas em simultâneo. A única inovação em termos morfológicos verifica-se com a introdução de recipientes que integrámos, não sem algumas reticências, no tipo vaso à chardon, que surge a partir da Fase 3, datável entre meados e finais do século VII a.C., sendo de assinalar que idêntica morfologia apareceu também fabricada a torno, por vezes com bandas pintadas na superfície externa, em outras áreas da Alcáçova de Santarém (Arruda 1999-2000: 196).

Esta tendência de predomínio das produções manuais, já verificada em outras áreas intervencionadas na Alcáçova (Arruda 1999-2000: 173), irá manter-se até à Fase 3 da estratigrafia de 2011, datável entre meados e finais do século VII a.n.e., momento a partir do qual estes vasos parecem ser, de certa forma, substituídos pelos de cerâmica cinzenta, com os quais partilham inegáveis similitudes formais, mantendo, porém, uma expressividade quantitativa notável até, pelo menos, aos finais do século VI a.n.e. (Fig. 12).

No quadro dos materiais de matriz orientalizante, um aspecto que é manifestamente importante e merece ser sublinhado centra-se na presença exclusiva de ânforas, aparentemente, importadas da costa de Málaga. Apesar deste conjunto ser escasso, sendo integralmente enquadrável no tipo 10.1.2.1 de Ramon Torres (1995), deve sublinhar-se a ausência, no espaço intervencionado, das produções locais da foz do Tejo (Tipo 1 - Sousa e Pimenta 2014). Ainda que a amostra seja reduzida e que fragmentos de ânforas do tipo 1 dessa produção estejam presentes em outras áreas escavadas na Alcáçova de Santarém, é tentador relacionar esta realidade com uma certa preferência por parte das comunidades locais por produtos mais exóticos ou eventualmente de melhor qualidade, oriundos de áreas mais longínquas do território peninsular. Neste pacote mais selectivo, poderá também enquadrar-se o possível fragmento de oil bottle, referido anteriormente. Mais difícil é, contudo, identificar os agentes responsáveis por essa selecção, uma vez que poderão corresponder quer aos grupos autóctones quer aos agentes fenícios-ocidentais que se teriam instalado no povoado (Arruda 1999-2000). Por outro lado, deve ainda salientar-se que em outras zonas da Alcáçova de Santarém se recolheram muitos mais exemplares integráveis em morfologias mais antigas (tipo 10.1.1.1 de Ramon Torres), mas também do tipo detectado no conjunto de 2001, vários dos quais são também muito possivelmente provenientes da costa meridional peninsular (Arruda 19992000: 205-206).

As restantes categorias cerâmicas "orientalizantes" exibem poucas alterações ao longo da diacronia verificada em 2001.

A de engobe vermelho regista modificações significativas apenas na última fase (Fase 6), para a qual se propõe uma cronologia de momentos avançados do século VI a.n.e., durante a qual surgem pratos de bordo mais largo e aplanado, tendência já verificada em outros conjuntos exumados em áreas próximas (Arruda 1999-2000: 185-186). É, contudo, de realçar a existência, nas Fases 5 e 6, de fragmentos destas produções que correspondem a vasos fechados, recuperados ainda em outras áreas do planalto scalabitano (Arruda 1999-2000: 188) e que 
possivelmente teriam uma funcionalidade mais vocacionada para usos sumptuários como seria o caso da oil bottle recuperada na Fase 1. Entre o conjunto de cerâmica de engobe vermelho, seria de destacar a escassez de taças o que, porém, poderá relacionar-se com uma questão de amostragem, uma vez que este tipo de vasos já tinha sido recolhido em intervenções anteriores (Arruda 1999-2000: 187).

No âmbito da cerâmica pintada em bandas, a forma mais recorrente é o pithos, sendo de assinalar a sua evolução morfológica sobretudo a partir da Fase 4 (primeira metade do século VI a.n.e.), a partir da qual surgem bordos mais apontados. No entanto, em outros conjuntos já estudados verificaram-se alterações morfológicas significativas nomeadamente no perfil do colo (Arruda 1999-2000: 192-193).

As restantes formas identificadas (urna de tipo Cruz del Negro e potes de bordo esvertido) são raras, não permitindo tecer considerações de grande valor cronológico e cultural. As características das pastas dos exemplares recolhidos pertencentes a estas duas categorias são macroscopicamente indiferenciáveis das produções da foz do Tejo, pelo que apenas a realização de análises químicas e petrográficas permitirá esclarecer se correspondem a produções locais ou a evidências de circulação de materiais a uma escala regional.

O mesmo problema coloca-se para as produções de cerâmica cinzenta, ainda que, neste caso, alguns elementos permitam admitir uma produção em área próxima. A abundância desta cerâmica no sítio e o facto de, ao longo da diacronia, o seu elenco morfológico absorver influências das produções manuais autóctones, como se observa em algumas taças de perfil carenado ou de paredes oblíquas, bem como ainda o pithos da Fase 5 , cuja produção em cerâmica cinzenta se desconhece nas áreas mais próximas da foz do Estuário, são elementos que permitem equacionar uma eventual produção local. Em termos morfológicos, assinalam-se as mesmas tendências já observadas em outros conjuntos artefactuais recolhidos no sítio em campanhas anteriores, com a predominância dos recipientes de tipo tigela, mas onde se incluem também pratos, muito possivelmente inspirados nas tipologias de engobe vermelho, taças carenadas e outras de paredes mais verticais (Arruda 1999-2000: 196-199). As pequenas formas fechadas são raras no conjunto, documentando-se apenas a partir da Fase 4 (primeira metade do século VI a.C.), o que corrobora as apreciações cronológicas já tecidas em trabalhos anteriores (Arruda 1999-2000: 201). É também de assinalar a presença, em alguns exemplares, de decorações brunidas que reflectem, uma vez mais, a partilha, com as produções manuais, de técnicas decorativas, evidência igualmente já observada anteriormente (Arruda 1999-2000: 203).

Para a cerâmica comum a torno, cuja forma dominante integra recipientes fechados de perfil em $\mathrm{S}$, possivelmente utilizados na confecção de alimentos, é possível também admitir, em certos casos, uma origem local, ainda que a eventualidade de um abastecimento da área de Lisboa não possa ser taxativamente negada.

Um outro aspecto que é importante salientar é a presença recorrente de artefactos relacionados com actividades metalúrgicas (copelas, algaravizes) que surgem apenas nos contextos de cronologia sidérica e que permanecem no elenco artefactual ao longo de toda a diacronia da ocupação aqui apresentada, refletindo a importância que estas actividades teriam no quadro económico da Alcáçova de Santarém, importância essa já atestada em outros conjuntos recuperados (Arruda 1999-2000: 215). Infelizmente, não dispomos ainda de análises que permitam determinar com segurança quais os metais trabalhados, ainda que seja provável que se trate de ouro ou de prata (Arruda 1999-2000: 215-216). No que diz respeito a este aspecto, cabe mais uma vez recordar que, em área próxima (Horto do Jardim), foram recolhidos também vários artefactos idênticos, estando associados a estruturas de combustão possivelmente destinadas a actividades metalúrgicas (Arruda 1999-2000: 216).

Os objectos de adorno são raros, incluindo apenas a conta de colar de pasta vítrea recuperada na Fase 2 ( $1^{\underline{a}}$ metade do século VII a.C.), infelizmente muito desgastada. Artefactos semelhantes eram já conhecidos (Arruda 1999-2000: 216), corroborando a utilização destes elementos na vida quotidiana dos antigos habitantes deste núcleo urbano.

Os dados artefactuais estudados no decurso deste trabalho corroboram, de forma inequívoca, as leituras que já foram concretizadas no quadro da interpretação da ocupação da Idade do Ferro da Alcáçova de Santarém (Arruda 1999-2000, 2005a, 2005b). Ao longo da sequência estratigráfica agora analisada, tornou-se evidente uma série de alterações ocorridas no quadro da cultura material, ao longo da primeira metade do $1^{0}$ milénio a.n.e., na sequência dos primeiros contactos com populações oriundas 
das costas mediterrâneas do território peninsular, que se instalaram, a partir de finais do século VIII a.C., no estuário do Tejo. Apesar das inovações na arquitectura, nos métodos de construção e no campo tecnológico (introdução de novas tecnologias que afectaram não só as actividades económicas desenvolvidas no sítio como a metalurgia, mas também a vivência quotidiana dos seus habitantes - uso de objectos de adorno de vidro, novas categorias, morfologias e decorações patentes nas cerâmicas), a realidade artefactual evidencia um claro enraizamento nas tradições seculares que remontam ao Bronze Final e que refletem o cariz profundamente autóctone dos seus habitantes. A expressividade das produções manuais, que dominam os inventários até aos momentos finais do século VII a.C., e a sua versatilidade funcional, que se estende desde o serviço de mesa ao armazenamento, passando, naturalmente, pela preparação e confecção de alimentos, demostra a preferência das comunidades que habitaram a Alcáçova de Santarém pelas tradições oleiras autóctones que, em muitos aspectos, seguem as mesmas tendências adoptadas ainda durante a fase final da Idade do Bronze. Este conservadorismo poderia ser lido como uma certa resistência (passiva ou activa) face aos elementos recém-chegados, de matriz orientalizante. No entanto, e apesar da sua menor representatividade, estes novos elementos parecem ter sido utilizados em simultâneo com os de tradição local, sendo incorporados em todas as funções do quotidiano (serviço de mesa - cerâmica de engobe vermelho e cinzenta; preparação e confecção de alimentos - cerâmica comum; armazenamento - cerâmica comum e pintada em bandas) como, aliás, já foi observado em outros conjuntos recuperados em área próxima (Arruda 1999-2000).

A orientalização do núcleo de Santarém parece, assim, ter sido progressiva, não tendo implicado o desaparecimento das identidades pré-existentes, pelo menos no quadro da cultura material. É também curioso notar que a categoria cerâmica orientalizante com mais sucesso no sítio é constituída pelas produções cinzentas, que, aliás, partilham com as tradições oleiras locais as mesmas tonalidade e acabamentos e, inclusivamente, algumas técnicas decorativas. Aliás, e como já atrás se referiu, a probabilidade de ter existido uma produção local desta categoria cerâmica é elevada, o que justificaria as estreitas relações que se verificaram em termos formais entre esta e as cerâmicas manuais. A incorporação de novos elementos tecnológicos que caracterizam as produções cinzentas (torno de oleiro, fornos aptos ao controle da temperatura e do processo de arrefecimento) implicou, contudo, uma permanente interacção com os grupos fenício-ocidentais que devem ter-se instalado no sítio, ainda que em contingentes reduzidos, sendo estes últimos, certamente, os agentes responsáveis pela transmissão destes novos conhecimentos (Arruda 1999-2000: 220). Tal fenómeno poderá, inclusive, estender-se a outras categorias cerâmicas (engobe vermelho, comum e pintada), apesar de, neste caso, ser ainda difícil de determinar a exacta origem destes recipientes, uma vez que as suas características físicas não se diferenciam com facilidade das produções mais meridionais do estuário do Tejo.

$\mathrm{Na}$ sequência de tudo o que foi anteriormente exposto, cabe, por fim, assinalar que a Alcáçova de Santarém constituí um caso de estudo excepcional no quadro da transição entre o Bronze Final e a Idade do Ferro no território actualmente português sendo, até ao momento, um dos raros casos onde foi possível documentar níveis estratigráficos sequenciais que ilustram este momento crucial da Proto-história peninsular.

Uma última referência é necessária no que diz respeito à etapa final da ocupação sidérica registada na campanha de 2001, e que foi datada em torno à segunda metade do século VI a.n.e. A ausência de vestígios de cronologia posterior não deve valorizar-se na leitura da ocupação do sítio, podendo relacionar-se quer com as intensas remodelações do espaço urbano sofridas durante a ocupação romano-republicana, que poderá ter destruído eventuais níveis da segunda metade do $1^{0}$ milénio, quer com dinâmicas internas de deslocações no quadro da área habitada, devendo aqui recordar-se que materiais associáveis a estas cronologias foram recuperados em áreas limítrofes (Arruda 1999-2000).

Esta ocupação da $1^{a}$ Idade do Ferro da Alcáçova de Santarém deve ser obrigatoriamente integrada na realidade das duas margens do Estuário do Tejo, área onde outros sítios, quer da foz (Lisboa, Almaraz) quer do espaço mais a norte (Alto do Castelo, Porto de Sabugueiro, Alto dos Cacos, na margem esquerda, Chões de Alpompé, Santa Sofia, na direita), revelam idêntica ocupação na matriz cultural. Contudo, algumas diferenças existem ao nível da cultura material que importa aqui destacar, diferenças que podem, contudo, justificar-se por distinções cronológicas, sobretudo para o início deste processo. Por outro lado, não pode esquecer-se nes- 
ta análise que a informação disponível para todos estes povoados é desigual, havendo os que foram escavados em áreas amplas (Santarém e, de certa forma, Lisboa e mesmo Santa Sofia) e outros em que os materiais resultam de recolhas de superfície (Alto do Castelo; Alto dos Cacos) ou de pequenas sondagens (Chões de Alpompé) ou ainda de contextos muito pouco fiáveis em termos estratigráficos (Porto de Sabugueiro). Para outros ainda não há estudos publicados que permitam leituras ao nível das presenças/ausências de fabricos cerâmicos (Almaraz).

Ainda assim, parece legítimo afirmar que a grande percentagem de cerâmica manual que se verifica em Santarém nas primeiras fases de ocupação não tem paralelo em outros sítios, concretamente em Lisboa ou nos Chões de Alpompé. Neste último, os vasos fabricados manualmente são escassos nos níveis da Idade do Ferro, que podemos datar dos séculos VII, mas sobretudo do VI a.n.e. Em Lisboa, e até ao momento, nos níveis de idêntica cronologia, final do século VII e século VI a.n.e. (Arruda 1999-2000; Calado et al. 2013; Filipe et al. 2014; Sousa e Pinto 2016; Sousa, Sarrazola e Simão 2016; Sousa 2016), as cerâmicas fabricadas manualmente são percentualmente quase insignificantes. Apenas em contextos mais antigos, como é o caso da Rua de São Mamede ao Caldas (Pimenta, Silva e Calado 2014), ela é relativamente abundante, em torno a $60 \%$, não atingindo, contudo, os valores registados em Santarém.

Em Santa Sofia (Vila Franca de Xira), sítio que pode, em termos cronológicos, ser comparável às fases iniciais de Santarém (finais do VIII/século VII a.n.e.), a cerâmica manual é considerável em termos numéricos, cerca de 70\% (Pimenta, Soares e Mendes 2013).

Estes dados relativos à cerâmica manual dos sítios do estuário do Tejo, que evidenciam a importante presença das comunidades indígenas nesses mesmos sítios, sobretudo nos mais a montante, devem apesar de tudo, ser matizados, ainda que o protagonismo daquelas comunidades no processo de orientalização desta região não se possa ser questionado. Contudo, e apesar de, como já referimos, a cerâmica manual cobrir todas as actividades quotidianas, concretamente o serviço de mesa e de cozinha, a verdade é que no que se refere à loiça de mesa desta categoria cerâmica, as pequenas taças carenadas de paredes finas, que podemos associar ao consumo de líquidos, são numericamente significativas. Esta realidade permite que se equacione a hipóte- se de os sólidos serem, maioritariamente, servidos à mesa em vasos a torno, muito especialmente em pratos e taças de engobe vermelho e os semi-sólidos ou colóides nas tigelas de cerâmica cinzenta, mas também nas de produção manual. Por outro lado, a loiça de cozinha é quase integralmente de cerâmica manual. Assim, e independentemente da importância da "agência" indígena, os hábitos sociais e também os que se relacionam com a dieta alimentar parecem alterar-se no início da Idade do Ferro, apesar de a forma de confecionar os alimentos não ter sofrido particulares alterações, uma vez que os tipos de panelas permanecem inalterados desde o Bronze Final, seja na forma seja na dimensão. Mais do que leituras étnicas redutoras (cerâmica manualindígenas; cerâmica a torno-colonizadores), as funcionalidades devem ser tidas em consideração neste tipo de abordagem.

Os processos de interacção entre os distintos agentes que actuaram no estuário do Tejo nos inícios da Idade do Ferro só podem, parece-nos, ser avaliados de acordo com análises como aquela que aqui ensaiámos, sendo imprescindível que outros estudos da mesma natureza sejam concretizados para a região. 

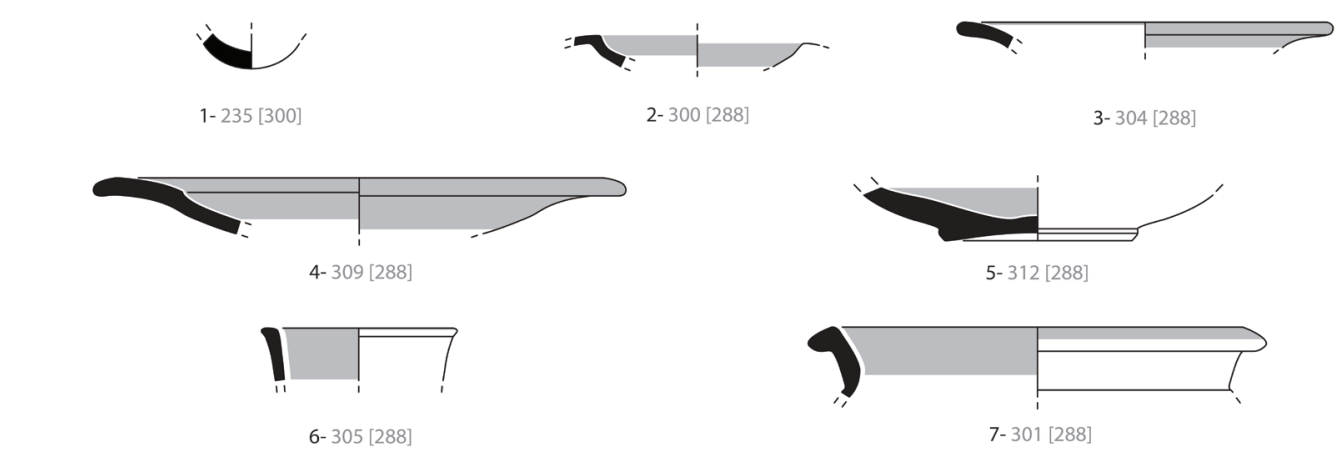

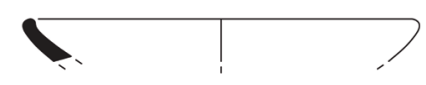

8- 255 [288]

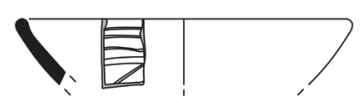

11- 254 [288]

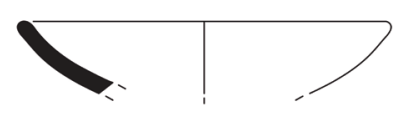

9- 249 [288]

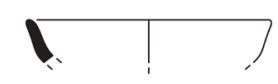

$12-457$ [289]

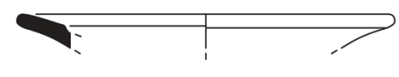

15- $260[288]$

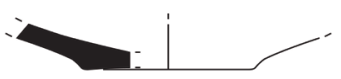

20-348 [288]

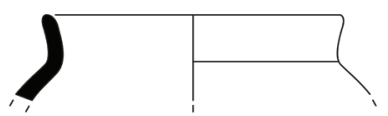

23-380 [288]

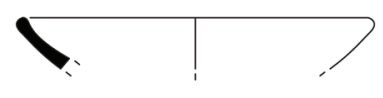

10- 251 [288]

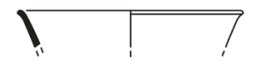

13- $263[288]$

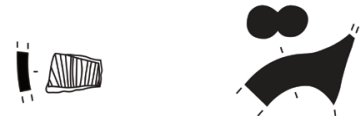

16- 474 [289]

17- $402[288]$

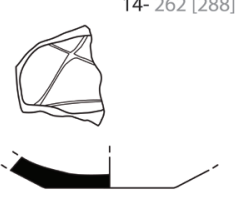

18- 265 [288]

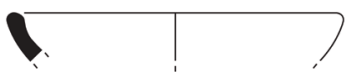

22-390 [288]

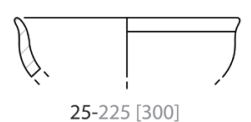

25-225 [300]

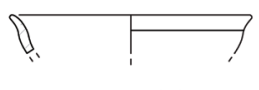

29-461 [289]

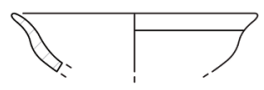

33- 361 [288]

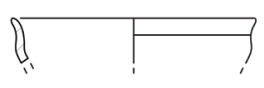

26-229 [300]

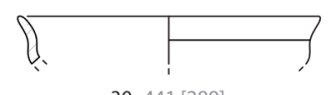

30- 441 [289]

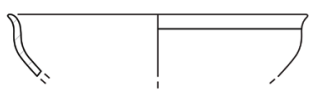

34- 278 [288]
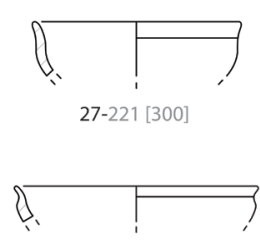

31- 247 [297]

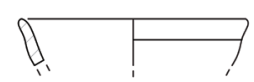

35- 467 [289]

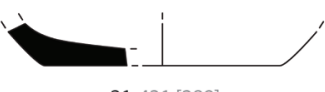

21-431 [289]

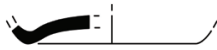

24-479 [306]
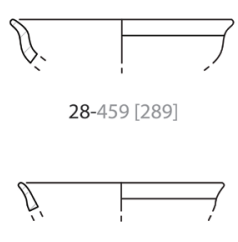

32- 242 [292]

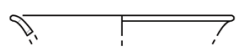

36- $356[288]$

Pintura vermelha

Fig. 13 - Materiais da Fase 1. 


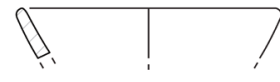

37- 292 [288]

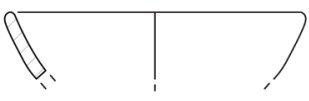

41- 241 [296]

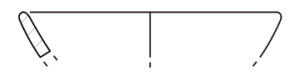

45- 283 [288]

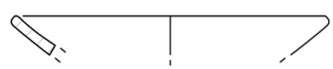

49- 389 [288]

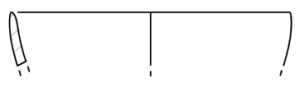

53- 354 [288]

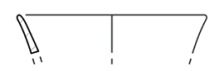

57- 1109 [290]
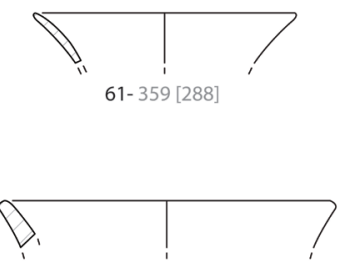

64- 432 [289]

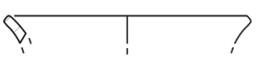

67-243 [292]
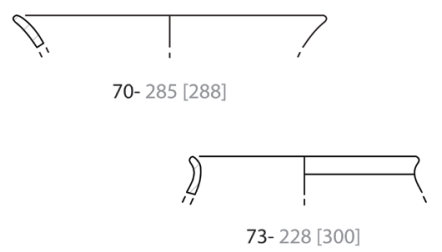

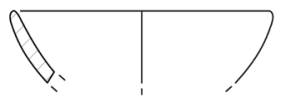

39- 456 [289]

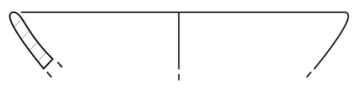

43- 447 [289]

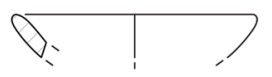

47- $232[300]$

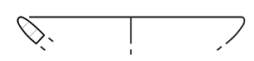

50- 291 [288]

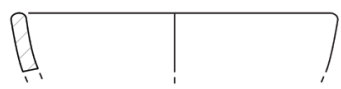

54- 458 [289]

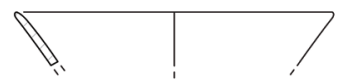

58- 475 [289]

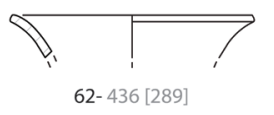

62- 436 [289]
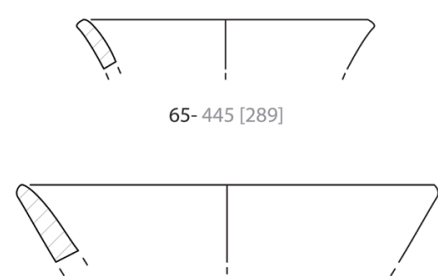

68- 384 [288]

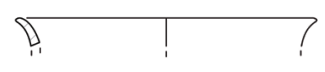

71-438 [289]

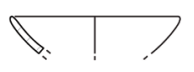

51- 288 [288]

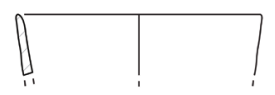

55- 289 [288]

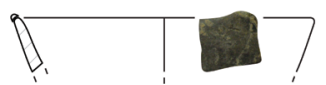

59- 281 [288]

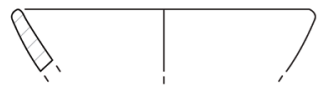

40- 223 [300]

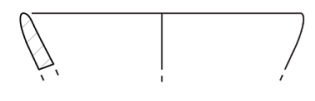

44- 280 [288]

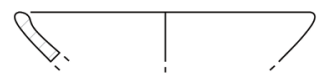

48- 381 [288]
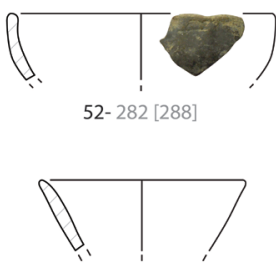

56- 446 [289]

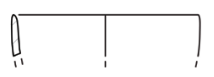

60- 463 [289]

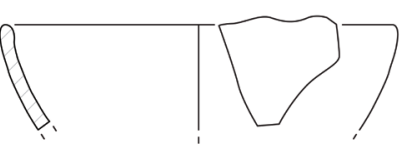

63- 238 [296]

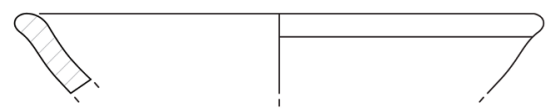

66- 267 [288]
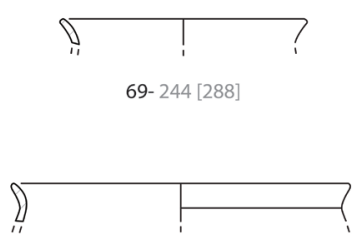

72- 437 [289]

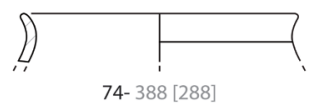

74- 388 [288] $10 \mathrm{~cm}$

Fig. 14 - Materiais da Fase 1. 


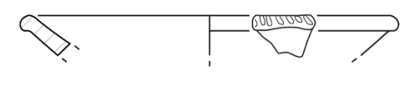

75- 272 [288]
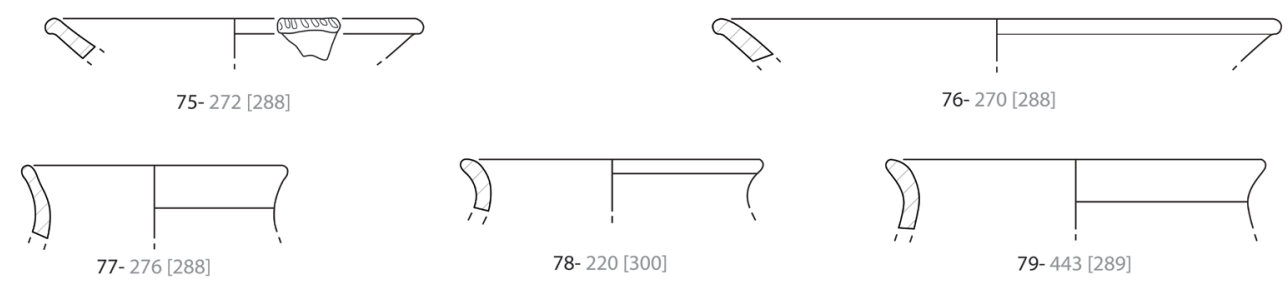

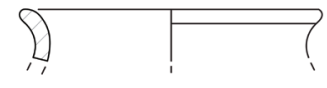

78- 220 [300]

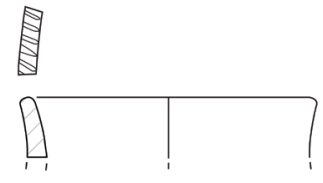

81- 240 [296]
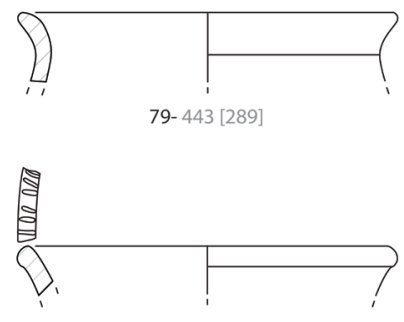

82- 488 [290]

80- 248 [297]

:

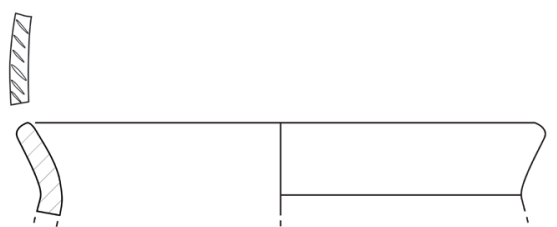

83- 387 [288]

?
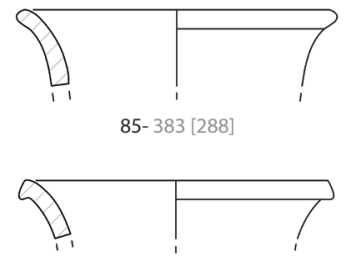

86- 444 [289]
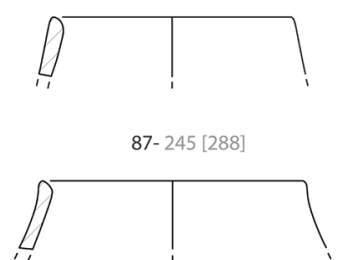

88- 382 [288]

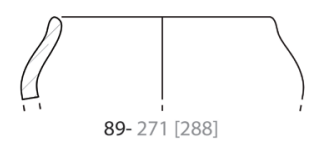

$\ddot{1}$. ति

101-403 [288]

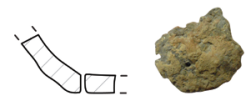

102- 310 [288]

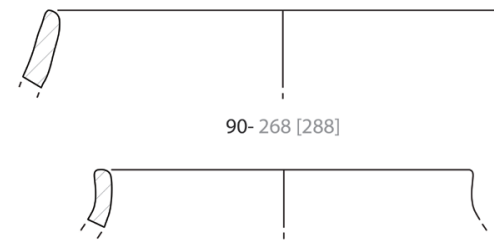

91- 442 [289]

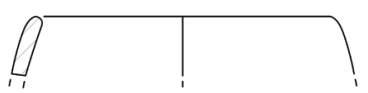

92- 224 [300]

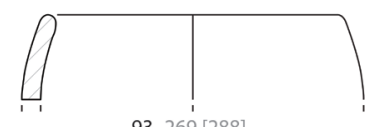

93- 269 [288]

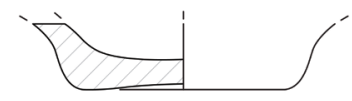

94- 430 [289]

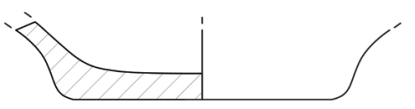

95- 336 [289]

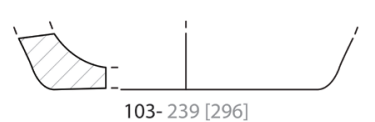

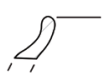

96- 246 [297]

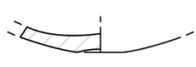

97-397 [288]

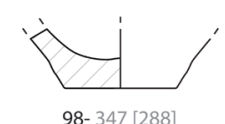

98- 347 [288]
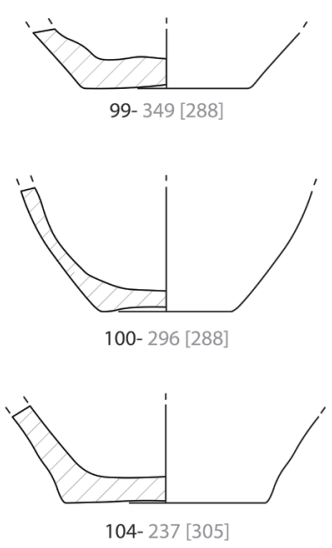

Fig. 15 - Materiais da Fase 1.

Revista Onoba, 2018, No o6 


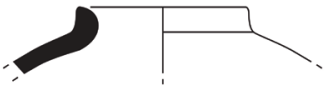

105- 495 [272]

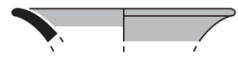

106- 496 [272]

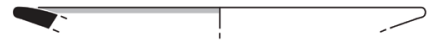

107- 23 [286]

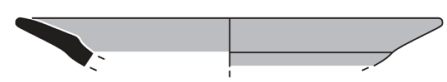

108- 36 [286]

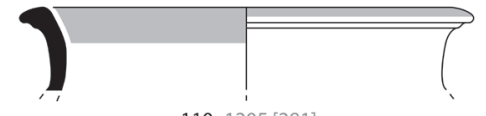

$110-1205[281]$
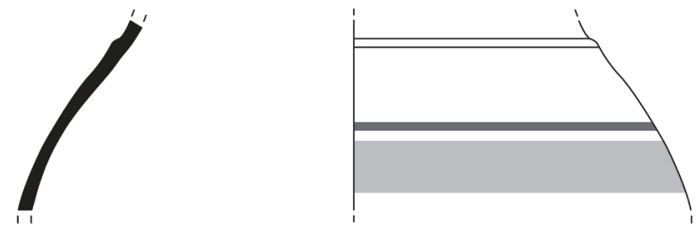

112- 487 [281]

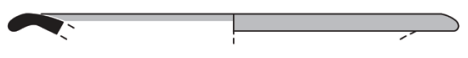

109- 40 [286]

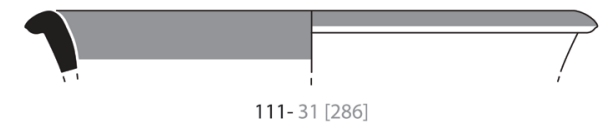

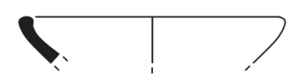

113- 4 [286]

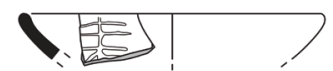

115- 35 [286]

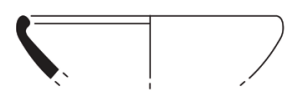

114- 14 [286]

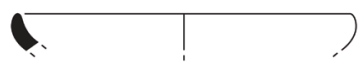

116- 499 [272]

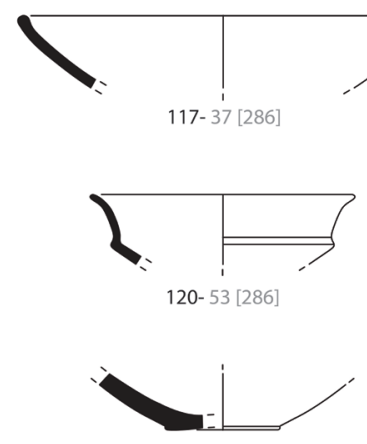

123- 63 [286]

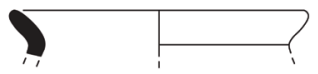

126- 485 [281]

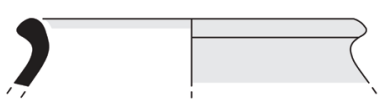

129- 480 [298]

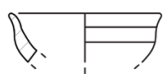

132- 15 [286]

Pintura vermelha

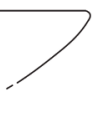

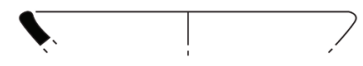

118- 502 [272]

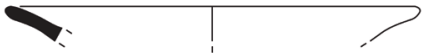

121- 62 [286]

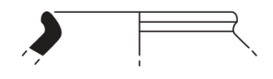

124- 3 [286]

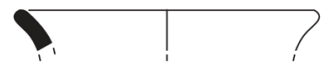

127- 481 [298]

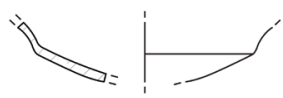

130- 548 [272]

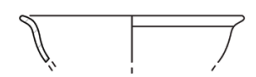

134- 512 [272]

Pintura cinzenta

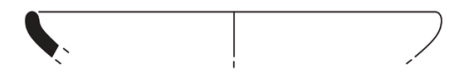

119- 19 [286]

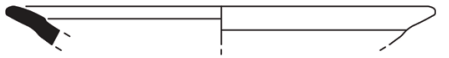

122- 17 [286]

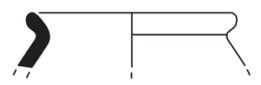

125- 21 [286]

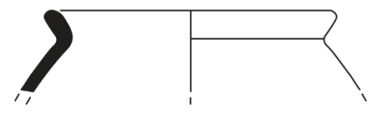

128- 55 [286]

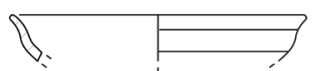

131- 510 [272]

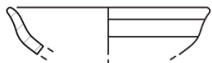

135- 516 [272]

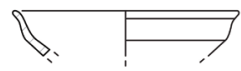

136- 527 [272]

Fig. 16 - Materiais da Fase 2. 


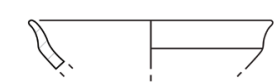

137- 417 [285]

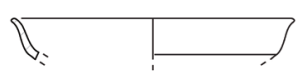

141- 419 [285]

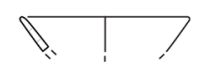

145- 49 [286]
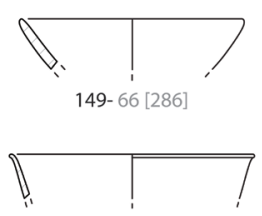

153- 18 [286]

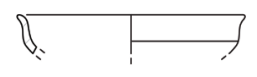

138- 524 [272]

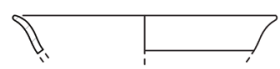

142- 513 [272]

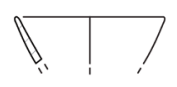

146- 26 [286]

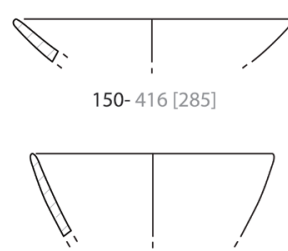

154- 39 [286]

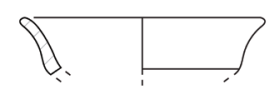

139- 509 [272]

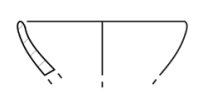

143- 411 [285]

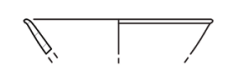

147- 11 [286]

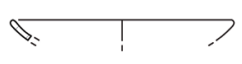

151- 52 [286]

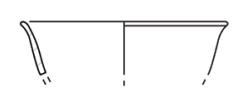

155- 511 [272]

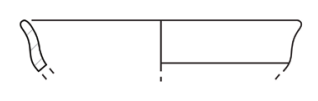

140- 508 [272]

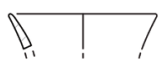

144- 2 [286]

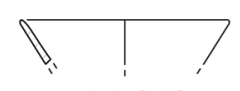

148- 56 [286]

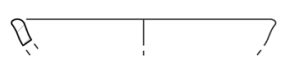

152- 647 [273]

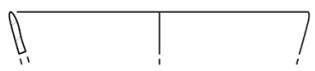

156- 531 [272]

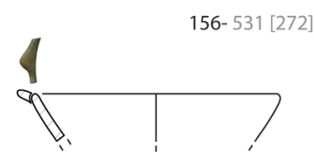

159- 545 [272]

$158-646[273]$

$\longrightarrow$

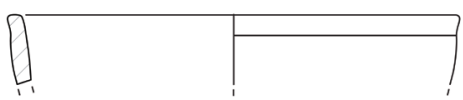

160- 1 [286]

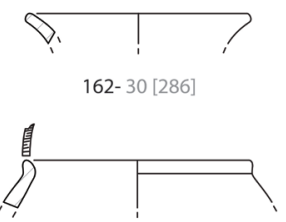

166- 534 [272]

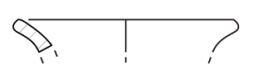

163- 505 [272]

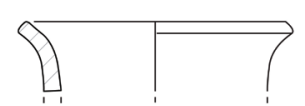

167- 421 [285]

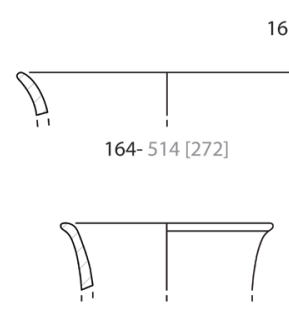

168- 539 [272]

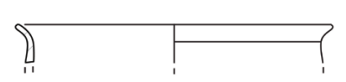

165- 515 [272]

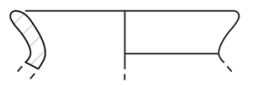

169- 47 [286]

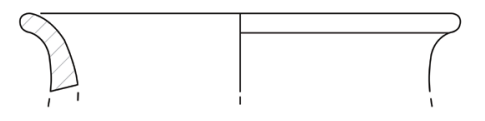

170- 482 [298]

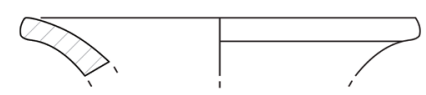

173- 503 [272]

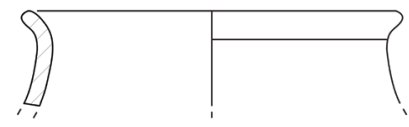

171- 422 [285]

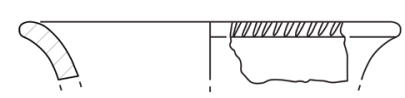

174- 427 [285]

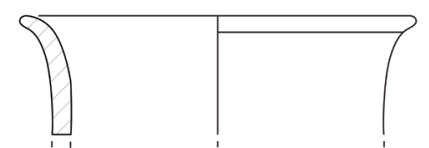

172- 429 [285]

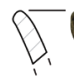

175- 46 [286]

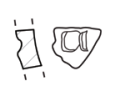

176- 428 [285]

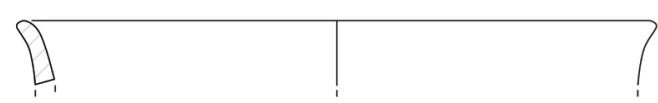

177- 12 [286]

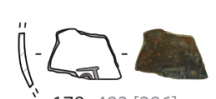

178- 493 [286]

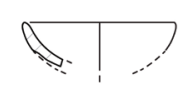

179- 532 [272]

Fig. 17 - Materiais da Fase 2. 


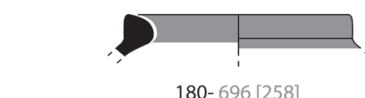

$180-696[258]$

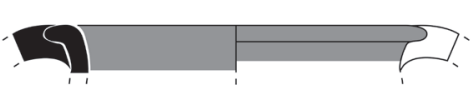

184- 1213 [274]

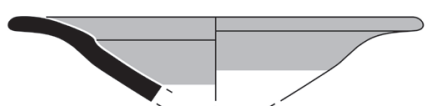

181- 695 [258]

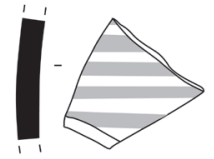

185- 740 [257]

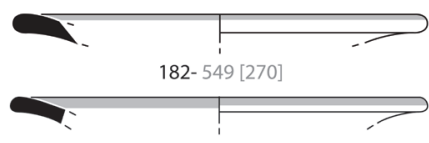

183- 606 [270]

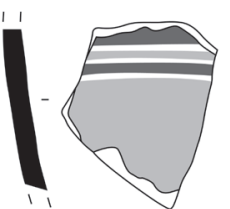

186- 733 [258]

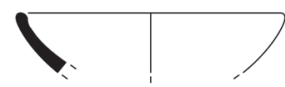

187- 598 [270]

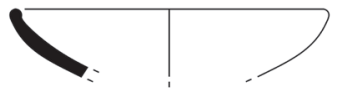

191- 658 [271]

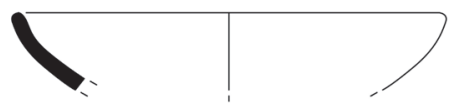

195- 596 [270]

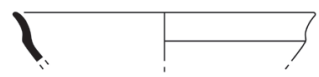

200- 678 [267]
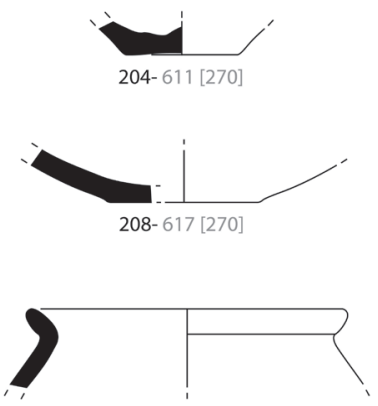

212- 621 [270]

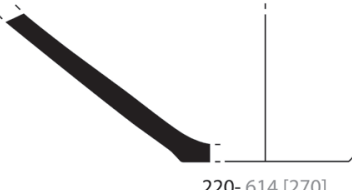

220- 614 [270]

Pintura vermelha
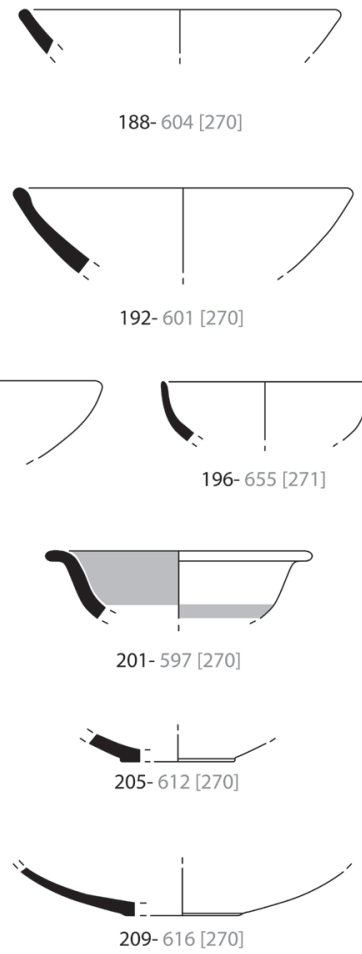

188- 604 [270]

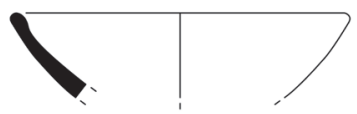

192- 601 [270]

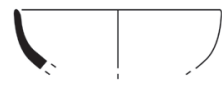

196- 655 [271]

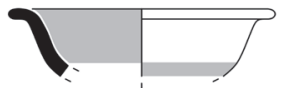

201-597 [270]

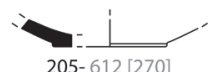

205-612 [270]

09- $616[27$

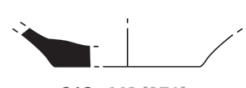

213- 662 [271]

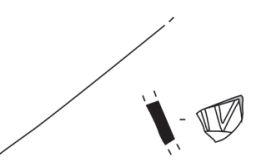

221- 633 [270]

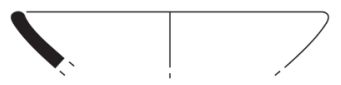

189- 742 [257]

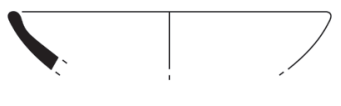

193- $656[271]$

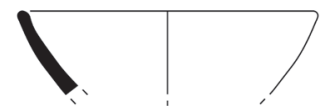

190- 743 [257]

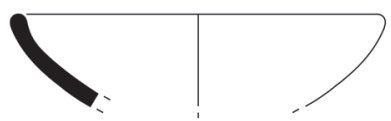

194- 620 [270]

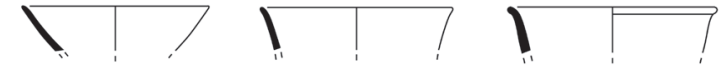

197- 657 [271]

198- 593 [270]

199- 649 [271]

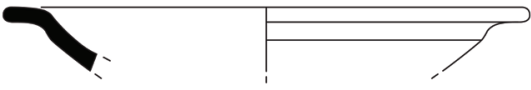

202- 592 [270]

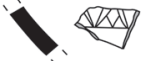

203- 629 [270]
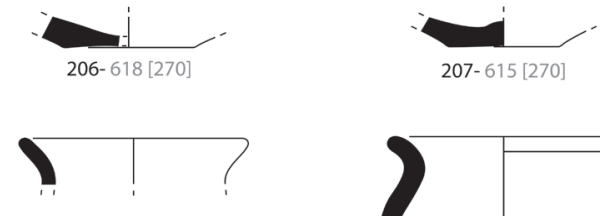

210- $741[257]$

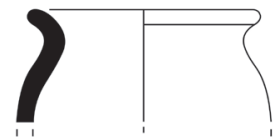

211- 731 [258]
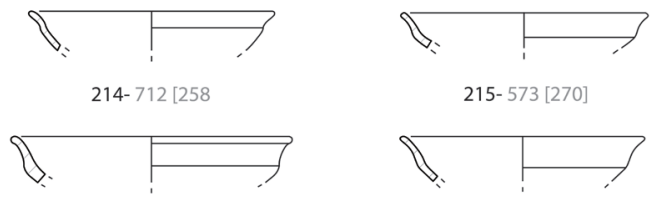

216- 707 [258]

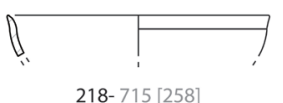

218- 715 [258]

Pintura cinzenta

Fig. 18 - Materiais da Fase 3. 


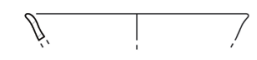

222- 661 [271]

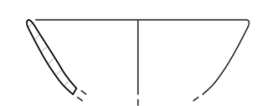

228- 563 [270]

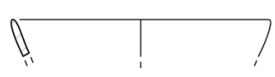

233- 570 [270]

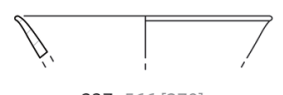

237- 566 [270]

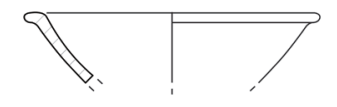

241- 672 [267]

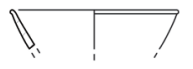

223- 567 [270]

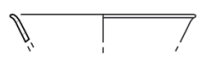

224- 569 [270]

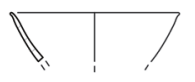

225- 564 [270]

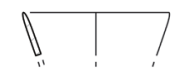

226- 1238 [274]

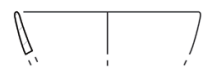

227- 1216 [274]

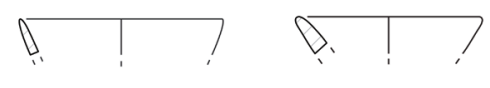

229- 717 [258]

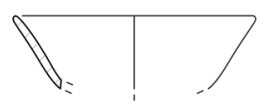

231- 571 [270]

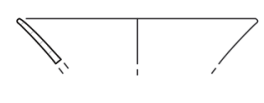

232- 572 [270]

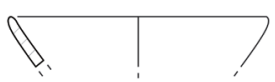

234- 708 [258]

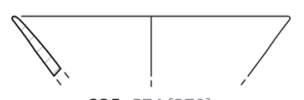

235- 574 [270]

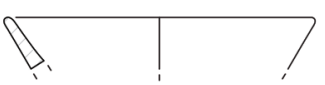

236- 576 [270]

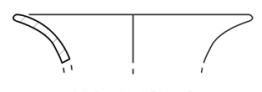

238- 714 [258]

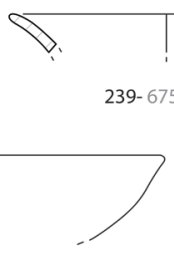

239- 675 [267]

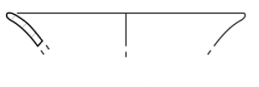

240- 627 [270]

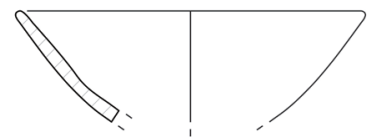

243- 699 [258]
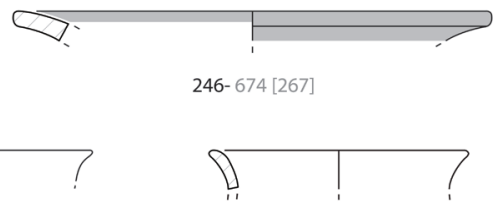

249- 701 [258]

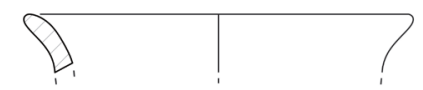

253- 703 [258]
250- 552 [270]

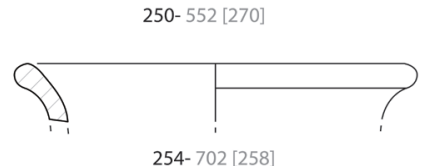

254- 702 [258]

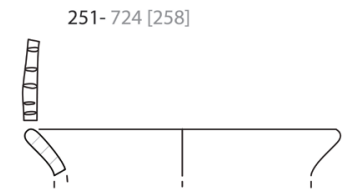

255- 584 [270]

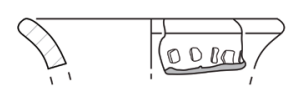

256- 561 [270]

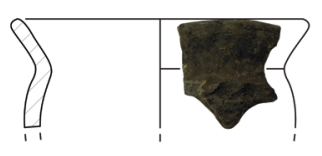

257- 577 [270]

Pintura vermelha

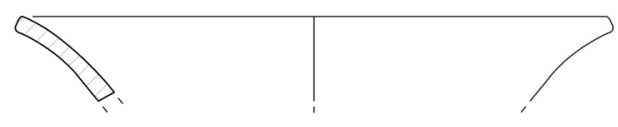

258- 697 [258]

id,

259- 613 [270] niven

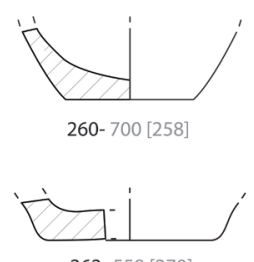

262- 558 [270]

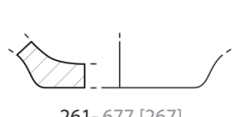

261- 677 [267]

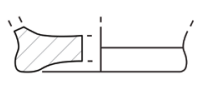

263- 559 [270]

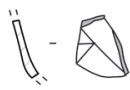

264- 630 [270]

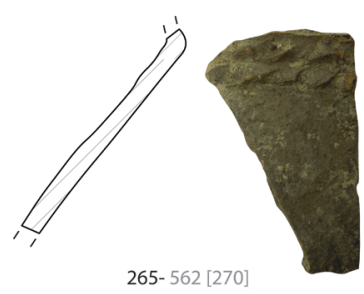

265- 562 [270]

Fig. 19 - Materiais da Fase 3. 

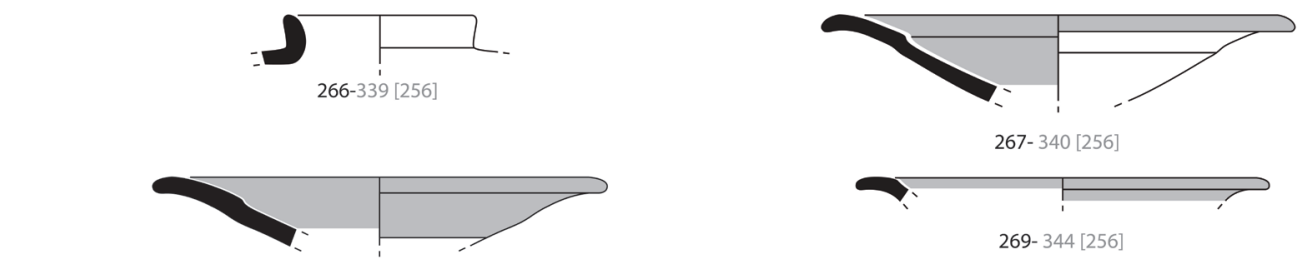

267- 340 [256]

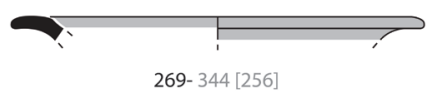

268- 782 [251]
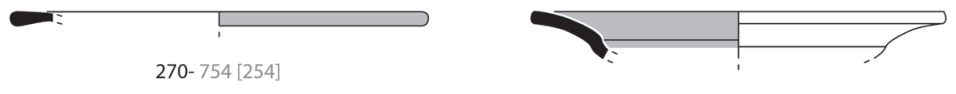

271- 1039 [242]

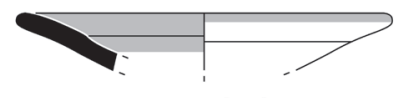

272- 693 [259]
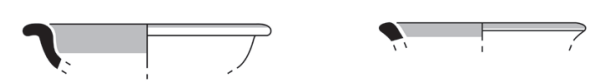

273- 1040 [242]

274- 694 [259]
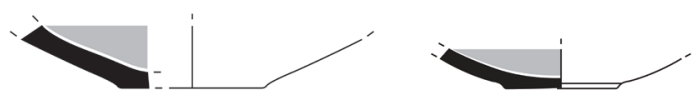

276- 341 [256]

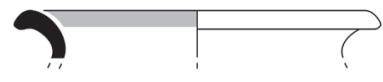

277- 1033 [242]

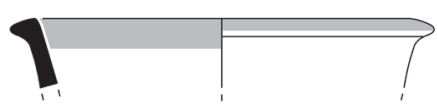

280- 690 [259]

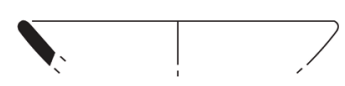

283- 333 [256]

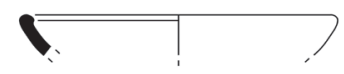

286- 768 [251]

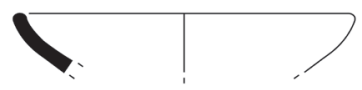

289- 760 [251]

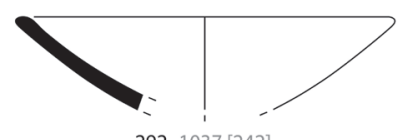

292- 1037 [242]

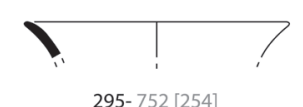

295- 752 [254]

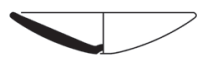

298- 1046 [242]

Pintura vermelha

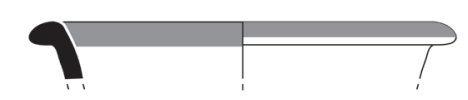

278- 758 [251]

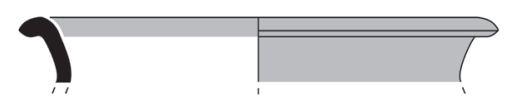

279- 1032 [242]

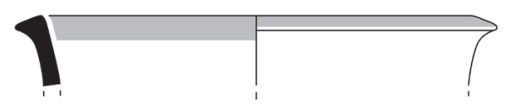

281- 757 [251]

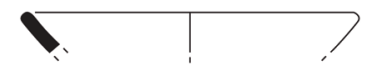

284- 317 [256]

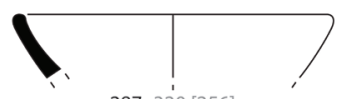

287-320 [256]

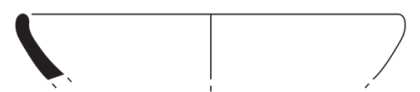

290- 1036 [242]

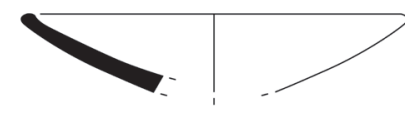

293- 762 [251]

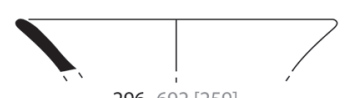

$296-692[259]$

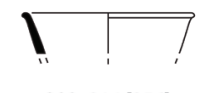

300- 314 [256]

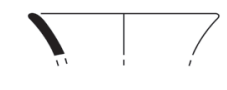

301- 1192 [248]

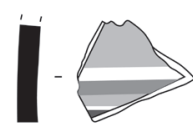

'282- 1083 [251]

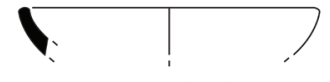

285- 318 [256]

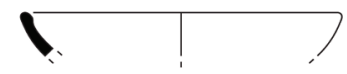

288- 316 [256]

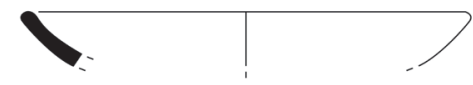

291- 1045 [242]

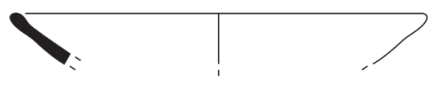

294- 1041 [242]

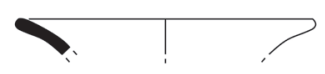

297- 745 [256]

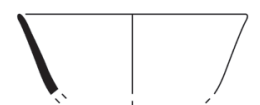

302- 1203 [249]

Fig. 20 - Materiais da Fase 4. 


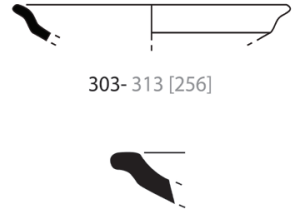

306- 1042 [242]
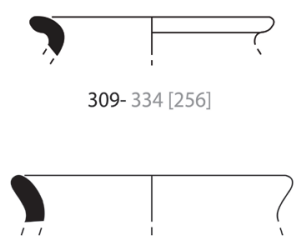

312- 1044 [242]
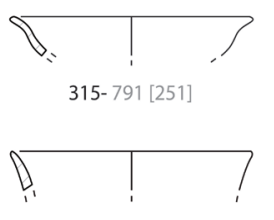

318- 330 [256]

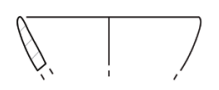

321- 327 [256]

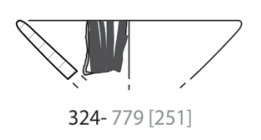

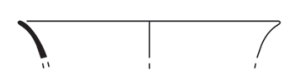

304- 1055 [242]

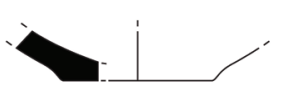

307- 345 [256]

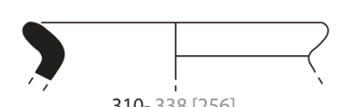

310- 338 [256]

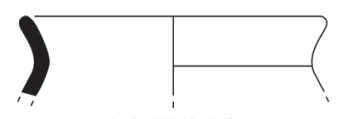

313- 774 [251]
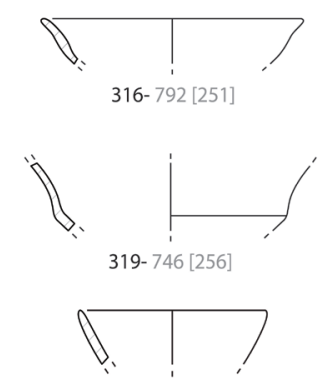

322- 331 [256]

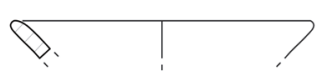

325- 770 [251]

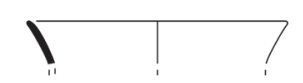

305- 1054 [242]

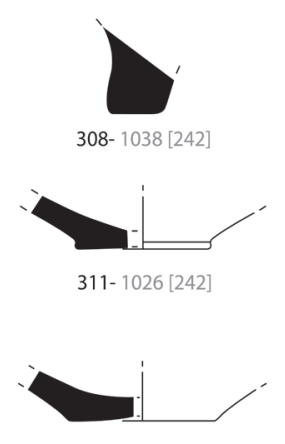

314- 1025 [242]
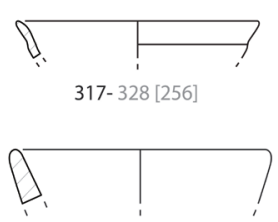

320- 750 [254]

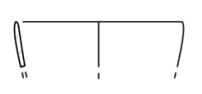

323-329 [256]

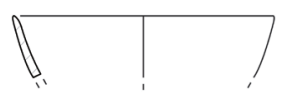

326- 777 [251]

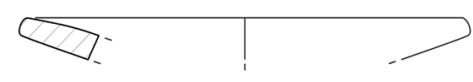

327- 1034 [242]

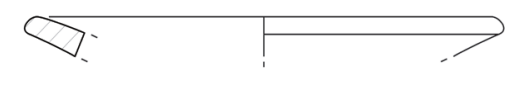

328- 1190 [248]

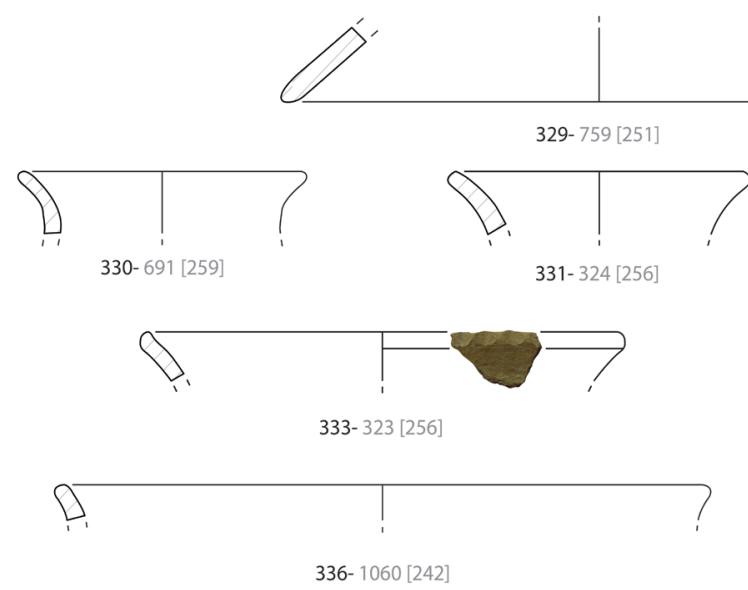




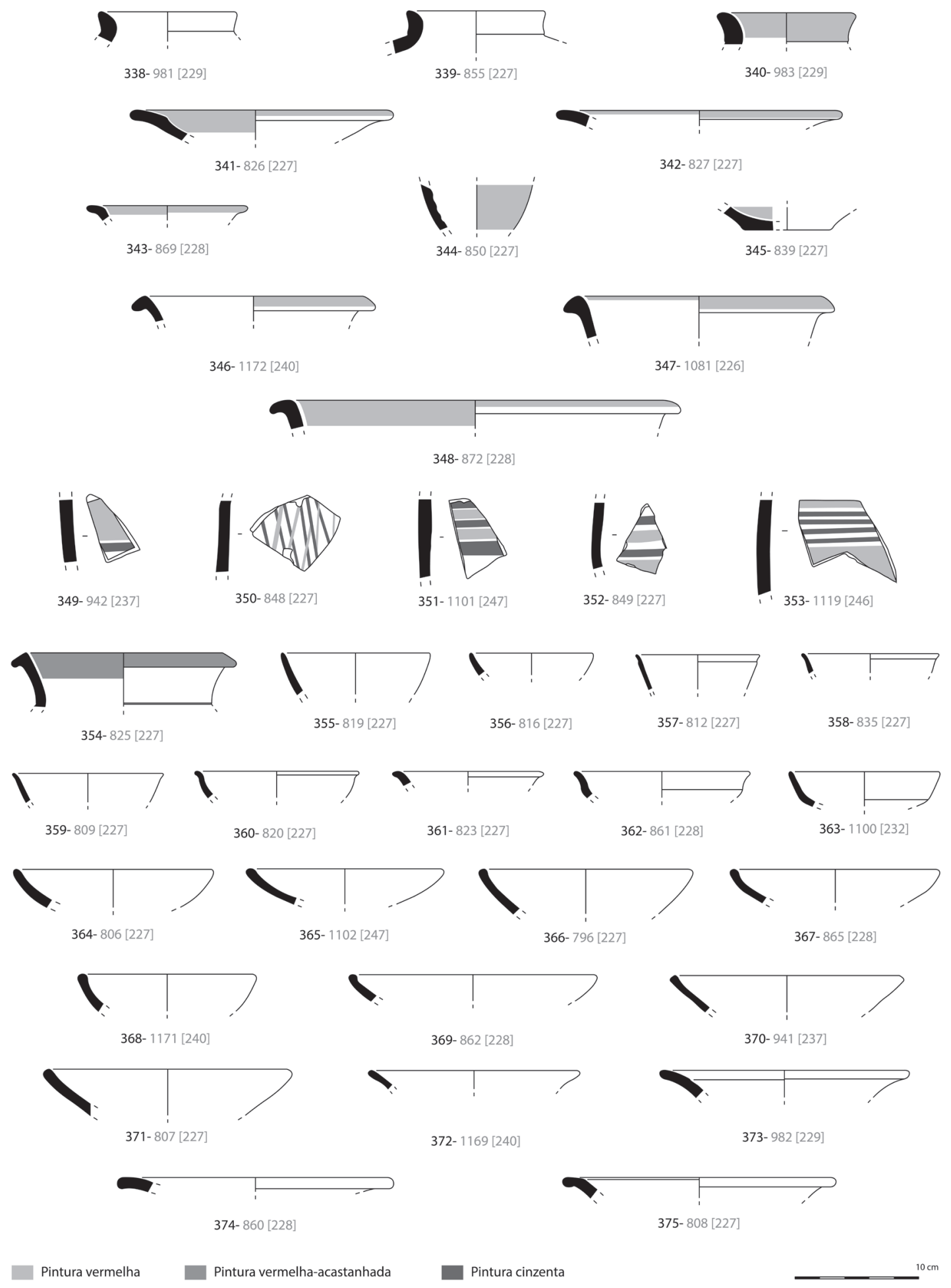

Fig. 22 - Materiais da Fase 5. 

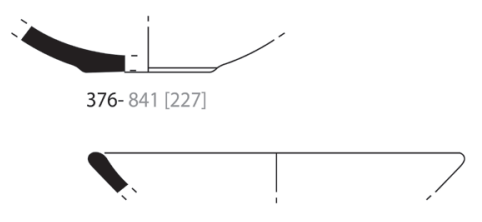

379- 831 [227]

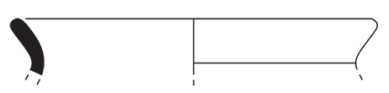

381-939 [237]
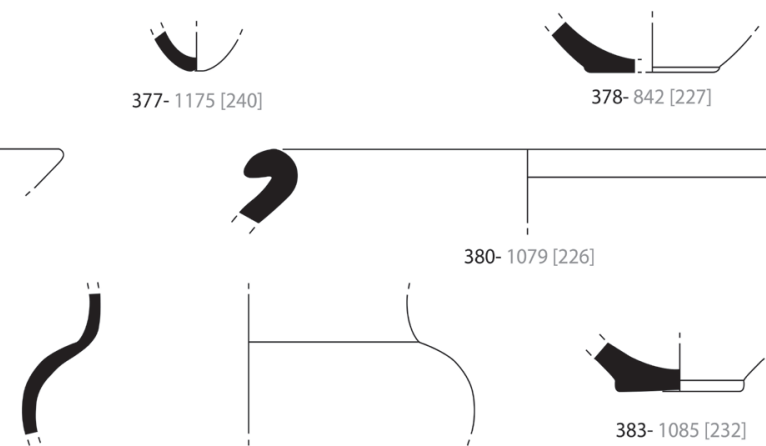

382- 943 [237]

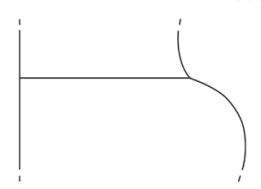

380- 1079 [226]

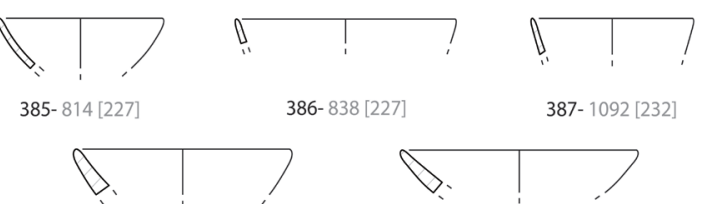

388- 1096 [232]

389- 985 [229]
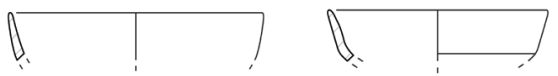

391- 870 [228]
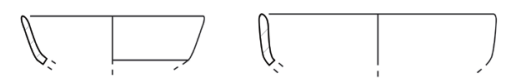

? ?

390- 863 [228]

392-858 [228]

393-852 [228]

394- 1211 [245]

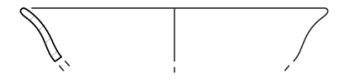

396- 1176 [240]
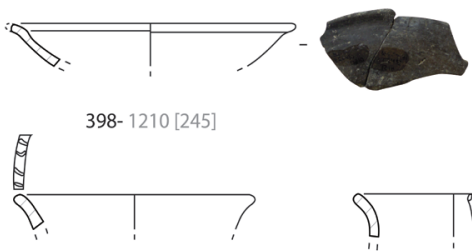

402- 824 [227]

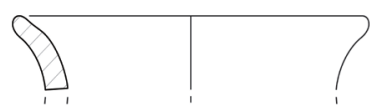

406- 984 [229]

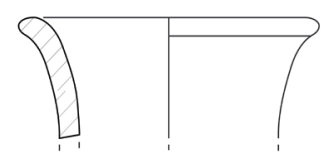

410- 1112 [246]

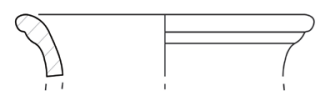

415- 1087 [232]

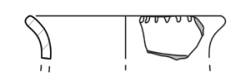

403- 1170 [240]

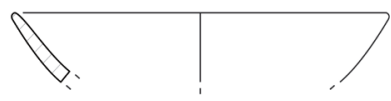

399- 1174 [240]

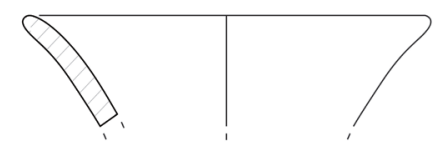

407- 1086 [232]

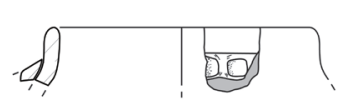

411- 1089 [232]

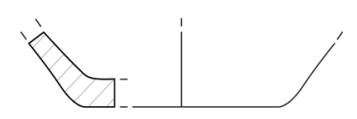

416- 1080 [226]

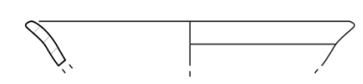

397- 1177 [244]

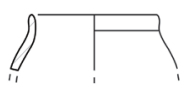

400- 1090 [232]

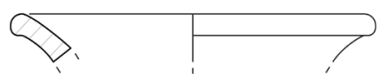

405- 833 [227]

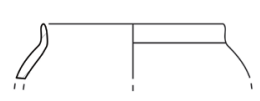

401- 1115 [246]

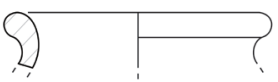

404- 832 [227]

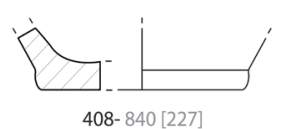

408- 840 [227]
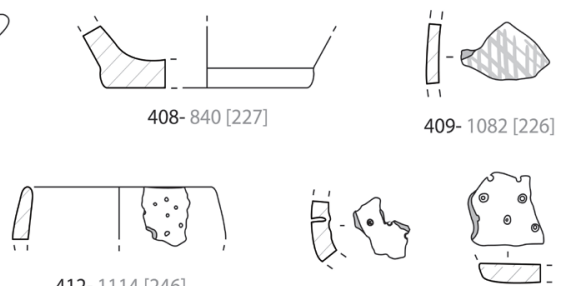

412- 1114 [246]

$\triangle Q R D$

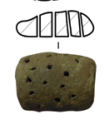

417- 1235 [245]

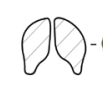

418- 1236 [245]

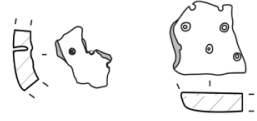

413- 1097 [232] 414- 1098 [237]

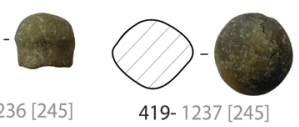

Fig. 23 - Materiais da Fase 5. 


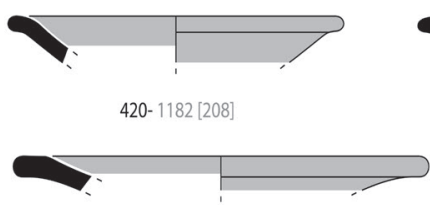

423- 1183 [208]

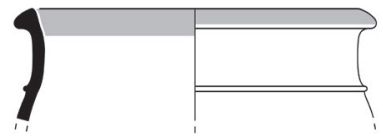

427- 944 [178]

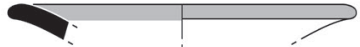

421-910 [213]

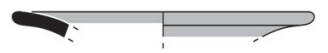

424- 1122 [219]

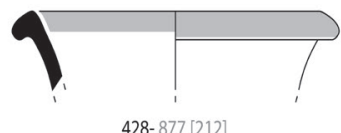

428-877 [212]

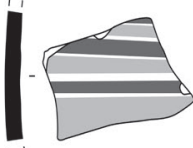

432- $1221[184]$

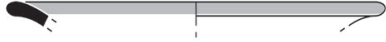

422- 913 [213]

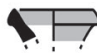

425- 665 [275]

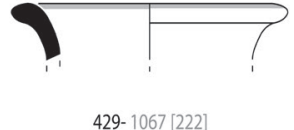

429-1067 [222]

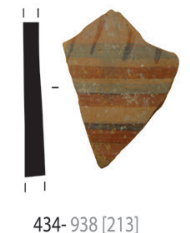

434- 938 [213]
433- 1194 [236]

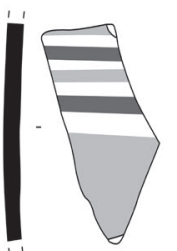

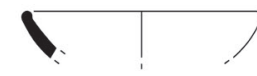

435- 900 [212]

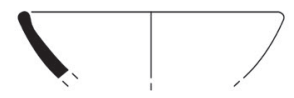

436- 977 [178]

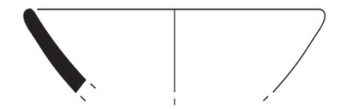

439-964 [178]

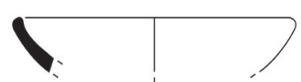

442- 1154 [219]

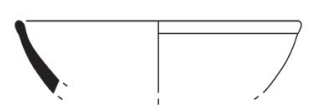

445- 918 [213]

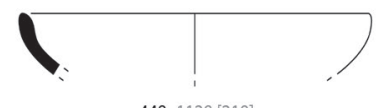

448- 1128 [219]

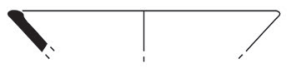

451- 965 [178]

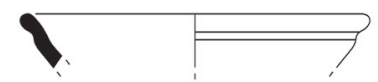

454- 945 [178]

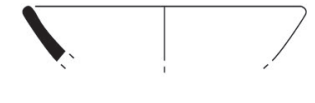

440- 1219 [184]

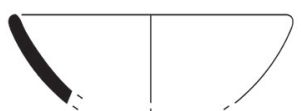

443- 1187 [197]

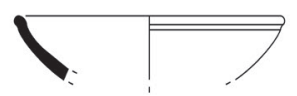

446- 1200 [207]

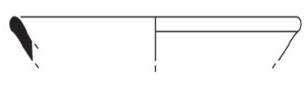

449- 929 [213]

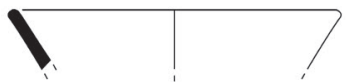

452- 1065 [222]

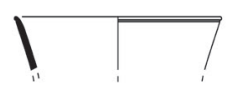

455- 1227 [184]

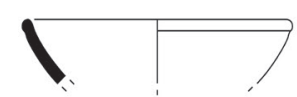

438- 1225 [184]

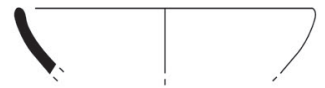

441- 667 [275]

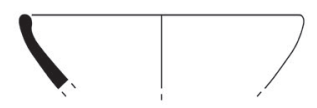

444- 894 [212]

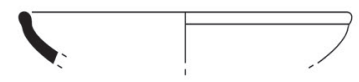

447- 921 [213]

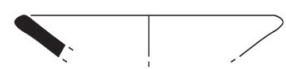

450- 949 [178]

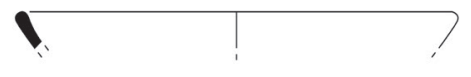

453- 1062 [181]

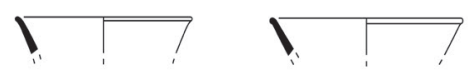

456- 897 [212]

457- 924 [213]

Fig. 24 - Materiais da Fase 6. 


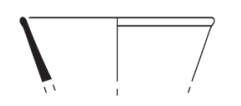

458-904 [212]

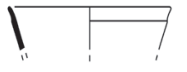

463-1120 [219]

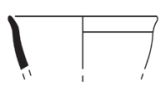

467-969 [178]

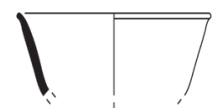

459-923 [213]

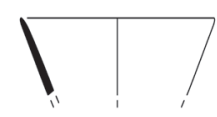

460- 1009 [215]

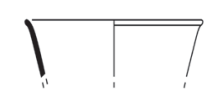

461- $670[275]$

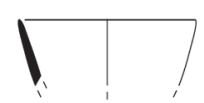

462- 976 [178]

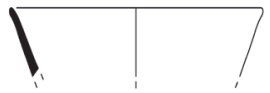

465- $930[213]$

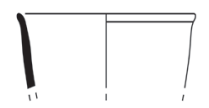

469-1233 [184]

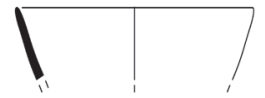

466- 972 [178]

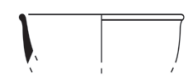

470-953 [178]

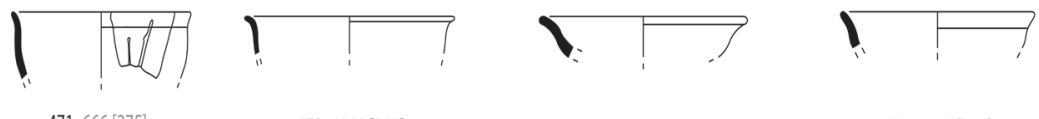

471- $666[275$

472- 1202 [207]

473- 891 [212]

474- 1007 [215]

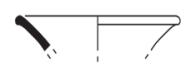

475- 1164 [219]

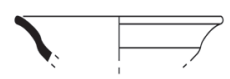

476- 1163 [219]

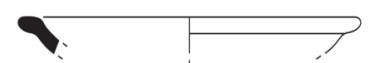

477- 922 [213]

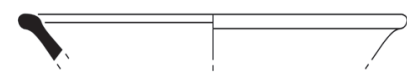

478-890 [212]

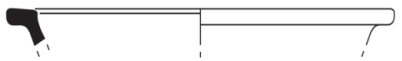

480-893 [212]

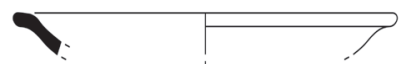

479- 912 [213]

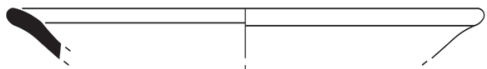

481- 885 [212]

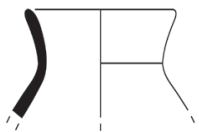

482-960 [178]

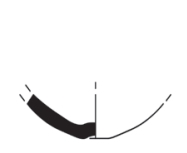

486- 1018 [215]

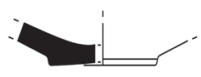

490- 1152 [219]

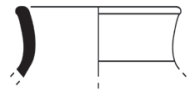

483-966 [178]

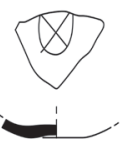

487- 1019 [215]

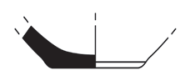

491-937 [213]

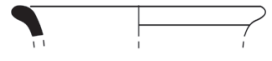

484- 974 [178]

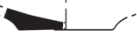

488-1207 [206]

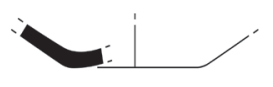

492-962 [178]

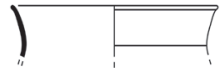

485- 954 [178]

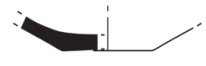

489- $1198[207]$

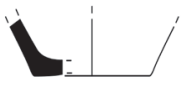

493- $950[178]$ $10 \mathrm{~cm}$

Fig. 25 - Materiais da Fase 6. 


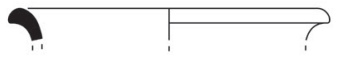

494- 947 [178]

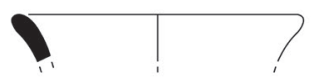

497- 951 [178]

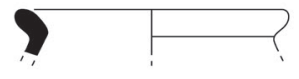

495- 898 [212]

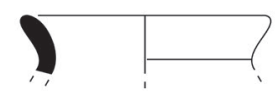

498- 1063 [181]

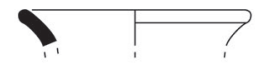

496- 1165 [219]

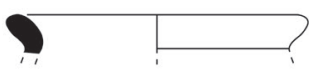

499- 1107 [233]

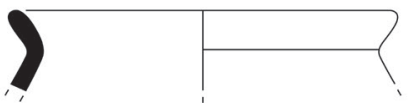

500- 1197 [207]

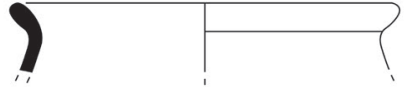

501- 1193 [236]

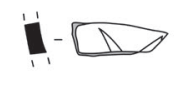

502- 1024 [215]

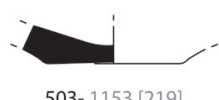

503-1153 [219]

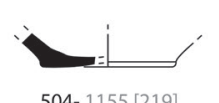

504- 1155 [219]

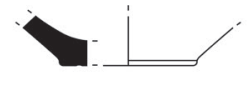

505-1196 [207]

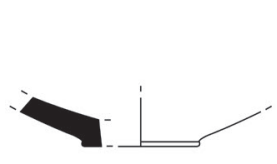

506- 1151 [219]

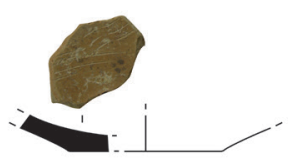

507-883 [212]

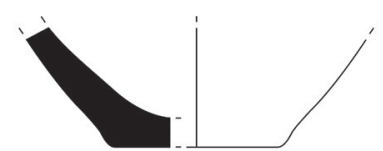

508- 1218 [184]

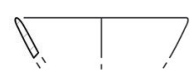

509- 932 [213]

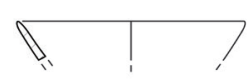

510- 1015 [215]

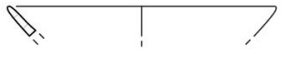

511- 997 [215]

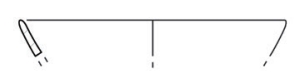

512- 1240 [215]

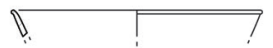

513- 1167 [219]

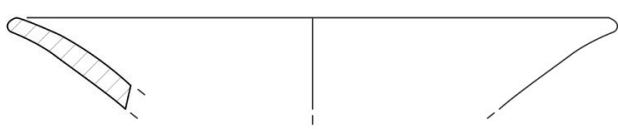

516- 993 [215]

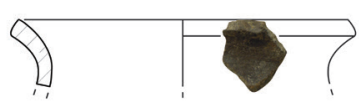

519- 903 [212]

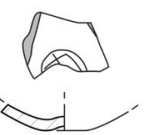

522- 980 [178]

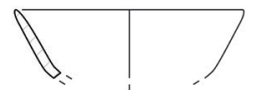

514- 1156 [219]

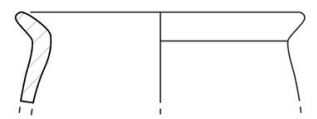

517- 968 [178]

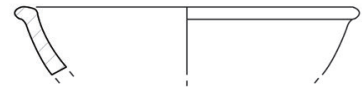

515- 967 [178]

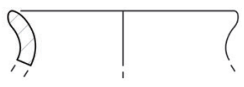

518- 994 [215]

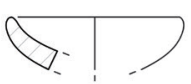

521-1020 [215]

520- 907 [212]

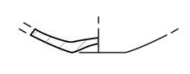

523- 979 [178]

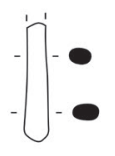

525- 671 [275]

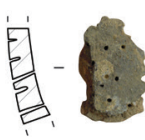

524- 909 [212]

Fig. 26 - Materiais da Fase 6. 
Bibliografia

Almagro Gorbea, M. (2008), "Bola de arcilla”, La necrópolis de Medellín II. Estudio de los hallazgos (M. Almagro Gorbea, dir.), Real Academia de la Historia, Madrid, 749-750.

Arruda, A. M. (1993), “A ocupação da Idade do Ferro da Alcáçova de Santarém no contexto da expansão fenícia para a fachada atlântica peninsular”, Estudos Orientais, 4, 193-214.

Arruda, A. M. (1999-2000), Los Fenicios en Portugal. Fenicios y mundo indígena en el centro y sur de Portugal (siglos VIII-VI a.C.), Publicaciones del Laboratorio de Arqueología de la Universidad Pompeu Fabra, Cuadernos de Arqueología Mediterránea, n. ${ }^{\circ}$ 5-6, Barcelona.

(2005a), "Orientalizante e pós-orientalizante no sudoeste peninsular: geografia e cronologias", Actas del III Simposio Internacional de Arqueología de Mérida: Protohistoria del Mediterráneo Occidental, vol. I, Anejos de Archivo Español de Arqueología, CSIC, Mérida, 277-303.

(2005b), "O $1^{0}$ milénio a.n.e. no Centro e no Sul de Portugal: leituras possíveis no início de um novo século", O Arqueólogo Português, Série IV, 3, 9-156.

Arruda, A. M., Freitas , V. e Vallejo Sánchez, J. (2000), "As cerâmicas cinzentas da Sé de Lisboa”, Revista Portuguesa de Arqueologia, 3-2, 25-59.

Arruda, A. M. e Sousa, E. (2015), "Late Bronze Age in Alcáçova de Santarém (Portugal)”, Trabajos de Prehistoria, 72-1, 176-187.

Aubet Semmler, M. E. (1976-1978),"La cerámica a torno de la Cruz del Negro (Carmona, Sevilla)", Ampurias, 38-40, 267-287.

Calado, M., Almeida, L., Leitão, V. e Leitão, M. (2013), "Cronologias absolutas para a I I Idade do Ferro em Olisipo - o exemplo de uma ocupação em ambiente cársico na actual Rua da Judearia em Alfama", Cira - Arqueologia, 2, 118-132.

Filipe, V., Calado, M. e Leitão, M. (2014), "Evidências orientalizantes na área urbana de Lisboa. O caso dos edifícios na envolvente da Mãe de Água do Chafariz d'El Rei”, Fenícios e Púnicos, por terra e mar, Actas do VI Congresso Internacional de Estudos Fenícios e Púnicos (A. M. Arruda, ed.), vol. 2, Centro de Arqueologia da Universidade de Lisboa, Lisboa, 736-747.
Freitas, V. (2005), As cerâmicas de engobe vermelho do Castelo de Castro Marim. Produção, consumo e comércio na Idade do Ferro Orientalizante Peninsular, Dissertação de mestrado apresentada à Faculdade de Letras da Universidade de Lisboa, 2 volumes, edição policopiada.

Pimenta, J., Soares, A. M. e Mendes, H. (2013), "Cronologia absoluta para o povoado préromano de Santa Sofia (Vila Franca de Xira)", Cira-Arqueologia, 2, 181-194.

Pimenta, J., Silva, R. e Calado, M. (2014), "Sobre a ocupação pré-romana de Olisipo. A intervenção arqueológica urbana da Rua de São Mamede ao Caldas n. ${ }^{0}$ 15”, Fenícios e Púnicos, por terra e mar, Actas do VI Congresso Internacional de Estudos Fenícios e Púnicos (A. M. Arruda, ed.), vol. 2, Centro de Arqueologia da Universidade de Lisboa, Lisboa, 712-723.

Ramon Torres, J. (1995), Las ânforas feníciopúnicas del Mediterráneo central $e$ occidental, Universitat de Barcelona, Barcelona.

Rufete Tomico, P. (1988-89), "Las ceramicas com engobe rojo de Huelva”, Huelva Arqueológica, X-XI, 10-40.

Sousa, E. (2014), A ocupação pré-romana da foz do Estuário do Tejo, Centro de Arqueologia da Universidade de Lisboa, Lisboa.

Sousa, E. e Pimenta, J. (2014), “A produção de ânforas no Estuário do Tejo durante a Idade do Ferro”, As Produções Cerâmicas de Imitação na Hispânia (R. Morais, A. Fernández e M.J. Sousa, eds.), vol. 1,Universidade do Porto, Porto, 303- 316.

Sousa, E. e Pinto, M. (2016), “A ocupação da Idade do Ferro na colina do Castelo de São Jorge (Lisboa, Portugal): novos dados das escavações realizadas na Rua do Recolhimento/Beco do Leão", Apontamentos de Arqueologia e Património, 11, 59-67.

Sousa, E., Sarrazola, A. e Simão, I. (2016), "Lisboa pré-romana: contributos das intervenções arqueológicas na Rua da Madalena”, Apontamentos de Arqueologia e Património, 11, 69-79.

Torres Ortíz, M. (2002), Tartessos, Real Academia de la Historia, Madrid. 
